\title{
A multistratigraphic approach to pinpoint the Permian-Triassic boundary in continental deposits: The Zechstein-Lower Buntsandstein transition in Germany
}

Frank Scholze ${ }^{a, f}$, Xu Wang ${ }^{b}$, Uwe Kirscher ${ }^{c}$, Johannes Kraft ${ }^{d}$, Jörg W. Schneider, ${ }^{a, f}$, Annette E. Götz $^{\text {eff }}$, Michael M. Joachimskig, Valerian Bachtadse ${ }^{\text {d }}$

a Technische Universität Bergakademie Freiberg, Geological Institute, Bernhard-von-CottaStr. 2, 09599 Freiberg, Germany; Frank.Scholze@geo.tu-freiberg.de;

Joerg.Schneider@geo.tu-freiberg.de

${ }^{b}$ Key Laboratory of Cenozoic Geology and Environment, Institute of Geology and Geophysics, Chinese Academy of Sciences, P.O. Box 9825, Beijing 100029, China; xuking@mail.iggcas.ac.cn

${ }^{c}$ ARC Centre of Excellence for Core to Crust Fluid Systems (CCFS) and The Institute for Geoscience Research (TIGeR), Department of Applied Geology, WASM, Curtin University, 6845 Perth, Australia

d Department of Earth and Environmental Sciences, University of Munich, Theresienstrasse 41, 80333 Munich, Germany; valerian@Imu.de

e University of Portsmouth, School of Earth and Environmental Sciences, Portsmouth, PO1 3QL, United Kingdom; annette.goetz@port.ac.uk

${ }^{f}$ Kazan Federal University, Institute of Geology and Petroleum Technologies, Kremlyovskaya str. 18, 420008 Kazan, Russia

g GeoZentrum Nordbayern, Universität Erlangen-Nürnberg, Schlossgarten 5, 91054 Erlangen, Germany; michael.joachimski@fau.de

Corresponding author: Frank Scholze; Geological Institute, Technische Universität Bergakademie Freiberg; Bernhard-von-Cotta-Str. 2; 09599 Freiberg; Germany; Frank.Scholze@geo.tu-freiberg.de; Tel.: 00493731393812. 


\section{Abstract}

The Central European Basin is very suitable for high-resolution multistratigraphy of Late Permian to Early Triassic continental deposits. Here, the well exposed transition of the lithostratigraphic Zechstein and Buntsandstein Groups of central Germany was studied for isotope-chemostratigraphy $\left(\delta^{13} \mathrm{C}_{\mathrm{org}}, \delta^{13} \mathrm{C}_{\mathrm{carb}}, \delta^{18} \mathrm{O}_{\mathrm{carb}}\right)$, major- and trace-element geochemistry, magnetostratigraphy, palynology, and conchostracan biostratigraphy. The analyzed material was obtained from both classical key sections (abandoned Nelben clay pit, Caaschwitz quarries, Thale railway cut, abandoned Heinebach clay pit) and a recent drill core section (Caaschwitz 6/2012) spanning the Permian-Triassic boundary. The ZechsteinBuntsandstein transition consists of a complex sedimentary facies comprising sabkha, playalake, aeolian, and fluvial deposits of predominantly red-colored siliciclastics and intercalations of lacustrine oolitic limestones. The new data on $\delta^{13} \mathrm{C}$ org range from $-28.73 \%$ o to $-21.67 \%$ showing multiple excursions. Strongest negative shifts correlate to single intercalations of oolites and gray-colored clayey siltstones, while isotopically more heavy shifts correspond to an onset of palaeosoil overprint. The $\delta^{13} C_{\text {carb }}$ range from -9.69 \%o to $1.34 \%$ with strongest variations recorded in dolomitic nodules from the Zechstein Group. A correlation of $\delta^{18} \mathrm{O}_{\mathrm{carb}}$-values with the carbonate content is interpreted to reflect diagenesis. In contrast to sedimentary facies shifts across the Zechstein-Buntsandstein boundary, majorelement values used as proxy $(\mathrm{CIA}, \mathrm{CI} *, \mathrm{CIA}-\mathrm{K})$ for palaeoclimate conditions indicate climatic stability. Trace-element data used for a geochemical characterization of the Late Permian to Early Triassic transition in central Germany indicate a decrease in the $\mathrm{Rb}$ at the Zechstein-Buntsandstein boundary.New palynological data obtained from the Caaschwitz quarry section reveal occurrences of Late Permian palynomorphs in the Lower Fulda Formation, while Early Triassic elements were recorded in the upper part of the Upper Fulda Formation. The present study confirms an onset of a normal-polarized magnetozone in the Upper Fulda Formation of the Caaschwitz quarry section supporting an interregional correlation of this crucial stratigraphic interval with the normal magnetic polarity of the basal Early Triassic known from marine sections in other regions. Based on a synthesis of the multistratigraphic data, the Permian-Triassic boundary is proposed to be placed in the lower part of the Upper Fulda Formation, which is biostratigraphically confirmed by the first occurrence date of the Early Triassic Euestheria gutta-Palaeolimnadiopsis vilujensis conchostracan fauna. Rare records of conchostracans reported from the siliciclastic deposits of the lower to middle Zechstein Group may point to its potential for further biostratigraphic subdivision of the Late Permian continental deposits.

Keywords: isotope geochemistry; major- and trace-elements; magnetostratigraphy; Conchostraca; biostratigraphy; central Germany 


\section{Introduction}

The sedimentary succession of the Zechstein and Buntsandstein Groups in Central Germany were the focus of numerous recent studies (e.g., Szurlies et al., 2003; Bachmann and Kozur, 2004; Korte and Kozur, 2005; Kozur and Weems, 2010; Hiete et al., 2006, 2013; Szurlies, 2013; Scholze et al., 2016) examining both the position of the Permian-Triassic boundary, and the palaeoenvironmental changes during the end-Permian mass extinction. As known from previous studies, the end-Permian mass extinction event has been linked to oceanic anoxia (Song et al., 2014), ocean acidification (e.g., Clarkson et al., 2015), or volcanism (Reichow et al., 2002). Controversially, global cooling was interpreted as potential mechanism for climate perturbation (e.g., Roscher et al., 2011), while more recently global warming is discussed to serve as a pace increasing catalyst but not as the initial reason of the end-Permian extinction (e.g., Chen et al., 2015). Additionally, asteroidal or cometary impact (e.g., Becker et al., 2001), or combinations of the above mentioned processes (e.g., Benton and Twichett, 2003) are debated as causes of the end-Permian extinction.

The end-Permian extinction was calibrated by radiometric dating of volcanic ash beds in marine deposits to occur in an interval of $0.061 \pm 0.048 \mathrm{Ma}$ (Burgess et al., 2014). However, the position of the Permian-Triassic boundary in continental deposits is still under discussion, since continental deposits are not directly correlated with marine index fossils to the Global Stratigraphic Scale. Additionally, the lack of radiometric age determinations of volcanic ash beds in continental deposits such as the Zechstein-Buntsandstein transition of the study area in central Germany is challenging the search of alternative time markers for regional to interregional correlation such as magnetostratigraphic reversals (e.g., Taylor et al., 2009; Glen et al., 2009), carbon isotopic values (e.g., Cao et al., 2008; Cui et al., 2015), or abrupt facies changes in the depositional system (e.g., Ward et al., 2000; Newell et al., 2010). Their implications on the position of the Permian-Triassic boundary serves as a prerequisite in order to contribute with multidisciplinary studies of continental deposits to the recent discussions on the causes of the extinction and associated environmental changes.

In the present study we conduct a multistratigraphic analysis of the crucial stratigraphic interval in continental deposits of the Zechstein-Buntsandstein transition in central Germany integrating new data on $\delta^{13} \mathrm{Corg}^{-}, \delta^{13} \mathrm{C}_{\text {carb- }}, \delta^{18} \mathrm{O}_{\text {carb-analyses, magnetostratigraphy, and }}$ biostratigraphy with palynomorphs and conchostracans (Crustacea: Branchiopoda). New geochemical results of major-/trace-element analyses are used for assessing proxies on palaeoclimatical conditions as previously done in continental Permian-Triassic boundary sections such as in the Bogda Mountains in NW-China (e.g., Thomas et al., 2011), western Guizhou and eastern Yunnan in South-China (e.g., Yu et al., 2007), the Karoo Basin in South Africa (e.g., Gastaldo et al., 2014), and northern Germany in the Central European Basin (e.g., Hiete et al., 2006, 2013). Our interdisciplinary study was performed on classical and new sections of the Zechstein-Buntsandstein transition in Thuringia, Saxony-Anhalt, and Hesse (Table 1). The work differs from previous studies in central Germany (e.g., Bachmann 
and Kozur, 2004; Korte and Kozur, 2005; Kozur and Weems, 2010, 2011) by the following aspects: (1) more dense sample intervals for $\delta^{13}$ Ccarb and $\delta^{18}$ Ocarb analyses; (2) studies of new key sections (i.e., Caaschwitz quarry at the Galgenberg hill, drill core Caaschwitz 6/2012); (3) use of latest published conchostracan biostratigraphic correlations to the Late Permian-Early Triassic continental deposits in central Russia (Scholze et al., 2015) and central Germany (Scholze et al., 2016).

Table 1. Locality names, outcrop situation and coordinates of the studied Late Permian-Early Triassic sections in central Germany.

\begin{tabular}{|l|l|l|}
\hline Section & Outcrop situation & Coordinates \\
\hline Caaschwitz 6/2012 drill core & $\begin{array}{l}\text { drill site at the Lerchenberg } \\
\text { hill; } 700 \text { m south of } \\
\text { Seifartsdorf }\end{array}$ & $\begin{array}{l}50^{\circ} 56^{\prime} 24.1^{\prime \prime} \mathrm{N}, \\
11^{\circ} 57^{\prime} 40.8^{\prime \prime} \mathrm{E}\end{array}$ \\
\hline Caaschwitz quarry & $\begin{array}{l}\text { abandoned quarry at the } \\
\text { Galgenberg hill; north of the } \\
\text { road Caaschwitz- } \\
\text { Seifartsdorf }\end{array}$ & $\begin{array}{l}50^{\circ} 57^{\prime} 6.59^{\prime \prime} \mathrm{N}, \\
11^{\circ} 58^{\prime} 23.61^{\prime \prime} \mathrm{E}\end{array}$ \\
\hline Heinebach & $\begin{array}{l}\text { abandoned clay pit; } 700 \mathrm{~m} \\
\text { northwest of Hergershausen }\end{array}$ & $\begin{array}{l}51^{\circ} 01^{\prime} 58.71^{\prime \prime} \mathrm{N}, \\
9^{\circ} 41^{\prime} 07.46^{\prime \prime} \mathrm{E}\end{array}$ \\
\hline Nelben & $\begin{array}{l}\text { abandoned clay pit; } 500 \mathrm{~m} \\
\text { north of Georgsburg at the } \\
\text { Saale bridge between }\end{array}$ & $\begin{array}{l}51^{\circ} 40^{\prime} 18.4^{\prime \prime} \mathrm{N}, 36.1^{\prime \prime} \mathrm{E} \\
\text { Nelben and Könnern }\end{array}$ \\
\hline Thale & $\begin{array}{l}\text { southern railway cut at the } \\
\text { Kirchberg hill }\end{array}$ & $\begin{array}{l}51^{\circ} 45^{\prime} 18.34^{\prime \prime} \mathrm{N}, \\
11^{\circ} 01^{\prime} 37.94^{\prime \prime} \mathrm{E}\end{array}$ \\
\hline
\end{tabular}

\section{Geological setting}

\subsection{Palaeogeography, lithostratigraphy, and facies}

During the Late Permian-Early Triassic the study area was located in the Central European Basin (from literature also known as "Southern Permian Basin", "Germanic Basin", or "Northwest European Basin"; e.g., Doornenbal and Stevenson, 2010; Beutler and Szulc, 1999; Ziegler, 1990). This basin extends West-East from England to eastern Poland and North-South from the Scandinavian Shield to the Brabant Massif, the Armorican Massif and the Vindelician-Bohemian Massif. In the Late Permian the sedimentation of the arid to semiarid Zechstein Group was governed by evaporitic cycles of marine ingressions from the Arctic Sea (e.g., Legler et al., 2005; Legler and Schneider, 2008). Therefore, the Zechstein Group 
composes seven evaporitic cycles (z1-z7) used for its litho- and cyclostratrigraphic subdivision (e.g., Richter-Bernburg, 1955; Käding, 2000) (Fig. 1). The study area was located at about $15^{\circ}-20^{\circ} \mathrm{N}$ (e.g., Stampfli and Borel, 2002) in the southern part of the Central European Basin, where these marine evaporitic cycles of the Zechstein Sea were partially replaced by siliciclastic equivalents. In particular, the higher part of the Zechstein Group (z4z6) consists almost without exception of haloturbated sandstones and pedoturbated siltstones deposited in a siliciclastic sabkha system. In the directly overlying Lower Fulda Formation (lower z7; upper part of the Zechstein Group) this facies gradually changes from decreasing palaeopedogenically overprinted sabkha deposits to an onset of internal lenticular- and flaser-bedded silt- and sandstones indicating a gradual shift towards a playa lake facies. The overlying Upper Fulda Formation (upper z7; uppermost part of the Zechstein Group) in the study area is marked at its base by an about $4 \mathrm{~m}$ thick sandstone with horizontal to irregular wavy bedding and occasionally intercalated small-scale channels representing a prominent facies change towards shallow subaquatic deposits of a fluvial to fluvio-lacustrine environment (Scholze in Schneider et al., 2014: p. 77-79). The overlying part of the Upper Fulda Formation (upper z7; Fig. 1) is built up of playa lake deposits consisting of $\mathrm{mm}$ - to $\mathrm{cm}$-thick alternating claystones to sandstones with internal lenticular and flaser bedding (e.g., Scholze et al., 2016).

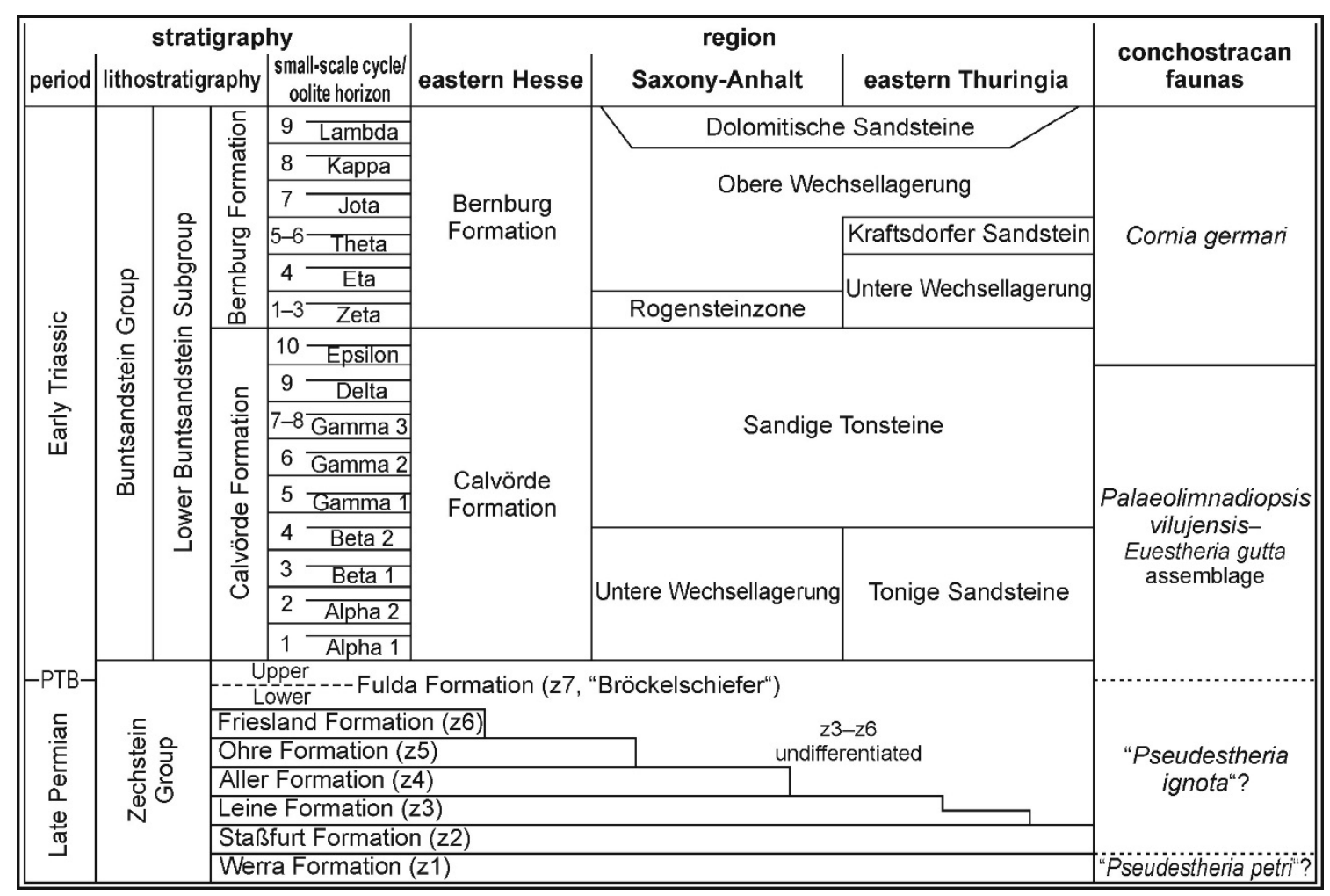

Fig. 1. Stratigraphy of the Zechstein-Buntsandstein transition in central Germany. Regional lithostratigraphic subdivision after Puff and Radzinski (2013); oolite horizons after Schulze (1969) and Radzinski (2008); small-scale cycles after Szurlies (2001). The vertical thickness is not to scale. "PTB" marks a proposed position of the Permian-Triassic boundary based on 
Scholze et al. (2016) and data of the present study. The Early Triassic conchostracan index species of the Cornia germari fauna and Palaeolimnadiopsis vilujensis-Euestheria gutta fauna refer to a biostratigraphic subdivision proposed by Schneider and Scholze (in press). The conchostracan form "Pseudestheria ignota" refers to the single specimen from the Langenthal Formation (?z2-z7; Zechstein Group) as reported in the present study (Fig. 10G). The form "Pseudestheria petri" refers to a single, well-preserved specimen from the Werra Formation in a drill core section at Kamp-Lintfort (North Rhine-Westphalia, western Germany) presented by Malzahn (1957) as discussed by Scholze et al. (2016).

The lithofacies of the Early Triassic sections of the Buntsandstein Group in the Central European Basin strongly differ from one another, depending on the respective palaeogeographic position within the basin. Sections located in more marginal parts of the basin consist predominantly of variously-colored, fine- to coarse-grained siliciclastics of alluvial, fluvial, fluvio-lacustrine, and aeolian deposits, while a playa lake facies is present in more central parts of the basin (Fig. 2). In ascending order the Lower Buntsandstein Subgroup of the study area is subdivided in two units, Calvörde and Bernburg Formations (Fig. 1). The oolitic limestones of the Lower Buntsandstein Subgroup were previously controversially interpreted either as lacustrine (e.g., Paul, 1982; Paul and Peryt, 2000; Knaust and Hauschke, 2005) or as marine (e.g., Usdowski, 1963; Langbein, 1985; Weidlich, 2007). The interbeddings of oolitic and stromatolitic limestone horizons of the central part of the basin are characteristic for the Lower Buntsandstein Subgroup and have high value for both lithostratigraphic subdivision and regional correlations within the study area (e.g., Schulze, 1969; Radzinski, 1999; Lepper et al., 2013; Röhling, 2013). Towards the southern margins of the study area the stromatolites and oolites are increasingly replaced by fine- to coarsegrained siliciclastics of fluvio-lacustrine and fluvial facies, which can be both subdivided and correlated by using "small-scale cycles" in the sense of Szurlies et al. (2003). 


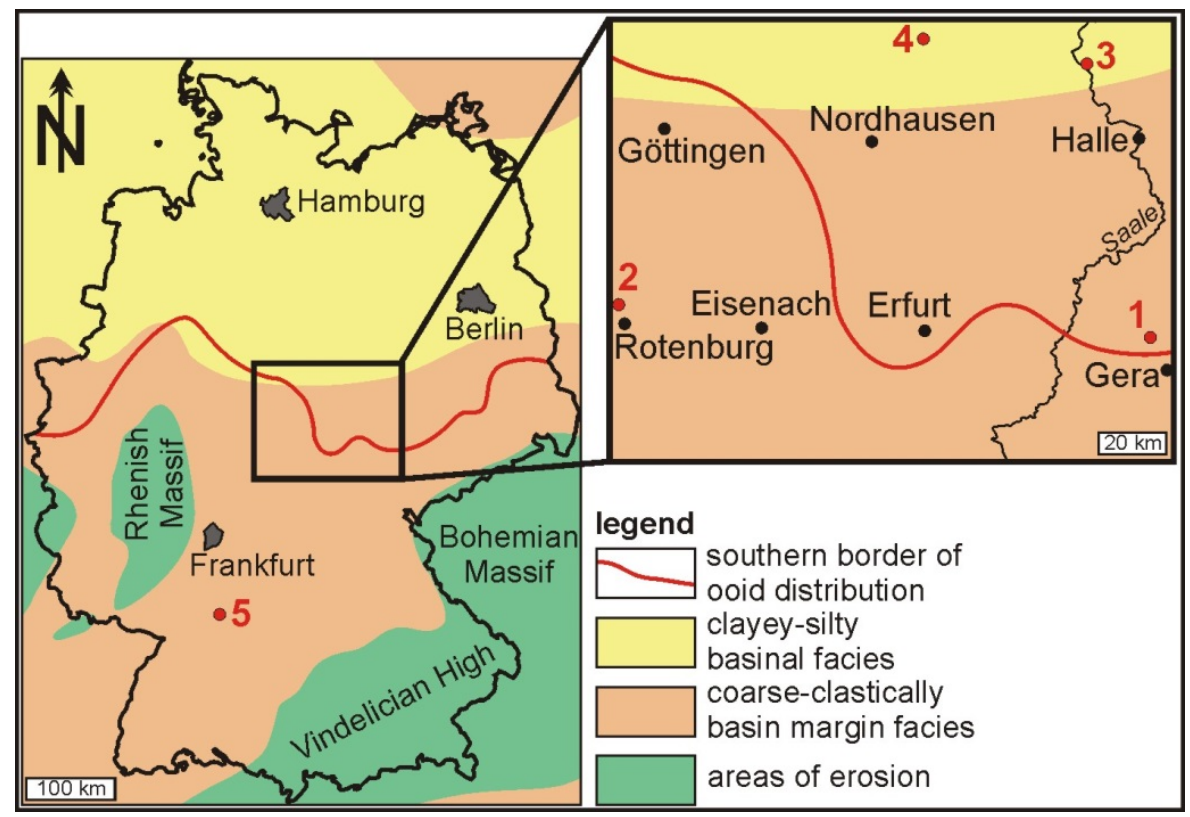

Fig. 2. Geographic positions of the studied sections and lithofacies distribution of the Lower Buntsandstein Subgroup (Early Triassic) in Germany: (1) Caaschwitz 6/2012 drill core and Caaschwitz quarries; (2) abandoned Heinebach clay pit; (3) abandoned Nelben clay pit; (4) Thale railway cut; (5) Langenthal BK2/05 drill core. Map after Scholze et al. (2016), Voigt and Gaupp (2000), Röhling and Lepper (2013).

\subsection{Biostratigraphy}

Besides conchostracans (e.g., Kozur and Weems, 2010; Scholze et al., 2016) and sparse records of bivalves (e.g., Hug and Vero, 2008), faunal elements are so far rarely described from the siliciclastic sabkha and playa deposits of the Zechstein Group. A more diverse fauna of various groups is known from the overlying Lower Buntsandstein Subgroup including notostracans (Voigt et al., 2008), xiphosurans (Hauschke and Wilde, 2000), conchostracans (Kozur and Seidel, 1983a; Scholze et al., 2016), ostracods (Kozur and Seidel, 1983b), and invertebrate trace fossils (Knaust and Hauschke, 2004, 2005) as well as sporadically reported fragments of both tetrapods and fishes (e.g., Dette, 1930; Wagenbreth, 1968; Kozur and Seidel, 1983b; Scholze et al., 2011). Among these groups, so far only the conchostracans were known for their high potential for high-resolution biostratigraphy of Permian-Triassic boundary sections in continental deposits (e.g., Kozur and Weems, 2010; Scholze et al., $2015,2016,2017)$. According to previous conchostracan studies of Kozur and Weems (2010, 2011), the Permian-Triassic boundary was suggested to correlate with the boundary between the Falsisca postera Zone and the overlying Falsisca verchojanica Zone, which coincides with the oolite horizon Alpha 2 of the second small-scale cycle of the Calvörde Formation (Lower Buntsandstein Subgroup) (e.g., Bachmann and Kozur, 2004). More recently, Scholze et al. (2016) recorded the first occurrence of an Early Triassic conchostracan assemblage of Palaeolimnadiopsis vilujensis and Euestheria gutta in the 
Upper Fulda Formation (upper z7) (Fig. 1) indicative for a stratigraphic position of the Permian-Triassic boundary within the Zechstein Group. Although Scholze et al. (2016) pointed out the necessity of further search for conchostracans from the Zechstein interval, this indication of an Early Triassic age is well supported by interregional occurrences of Euestheria gutta in Early Triassic (Induan) sections, such as in South China (e.g., Chu et al., 2013) and Russia (e.g., Scholze et al., 2015).

Records of plant remains are rare, except for the lower part of the Zechstein Group from which micro- and macrofloral elements were previously reported from the German and Polish parts of the Central European Basin (e.g., Fijałkowska, 1995; Bauer et al., 2013). In contrast, palynomorphs from the uppermost Zechstein Group to the Lower Buntsandstein Subgroup were more frequently reported (e.g., Heunisch, 1999) and their use for biostratigraphic subdivision was recently summarized by Backhaus et al. (2013, and references therein). In previous works, the position of the Permian-Triassic boundary based on palynomorphs has been placed at different stratigraphic levels. According to Ecke (1986) an assemblage of Lundbladispora obsoleta, Densoisporites playfordii, and Kraeuselisporites apiculatus was proposed for correlation of the Permian-Triassic boundary between the oolite horizons Beta 1 and Beta 2, corresponding to an interval between the third and fourth small-scale cycles of the Calvörde-Formation. In contrast, Kozur (1999) correlated the boundary between a Lundbladispora obsoleta-Lunatisporites noviaulensis Zone and an overlying Lundbladispora willmotti-Lunatisporites hexagonalis Zone with the PermianTriassic boundary, whereby the latter zone begins in the lower part of the second small-scale cycle of the Calvörde Formation (Kozur and Bachmann, 2005: Fig. 4). This inconsistency demonstrates the current need of reinvestigations of the palynomorph assemblages of the Zechstein-Buntsandstein transition in order to use them for high-resolution biostratigraphic correlations.

\subsection{Chemostratigraphy}

The central and northern German parts of the Central European Basin were recently the focus of various isotope analysis of both carbonate (e.g., Bachmann and Kozur, 2004; Korte and Kozur, 2005; Weidlich, 2007) and organic carbon (e.g., Hiete et al., 2013). According to previous studies of Korte and Kozur (2005), minima in the $\delta^{13} \mathrm{C}$ values measured on oolitic limestones of the Calvörde and Bernburg Formations (Lower Buntsandstein Subgroup) were proposed to correspond in their stratigraphic position to certain isotope minima of marine sections. In particular, Korte and Kozur (2005) recorded a $\delta^{13} C_{\text {carb }}$ minimum of $-4.2 \%$ immediately above the Falsisca postera Zone as an important stratigraphic marker for a proposed correlation of the Permian-Triassic boundary. According to previous studies of Kozur and Weems (2010: p. 365) in the abandoned clay pit section at Nelben (Saxony-Anhalt, central Germany), this negative $\delta^{13} \mathrm{C}$ excursion lies in the oolite horizon Alpha 2 (at the base of the second small-scale cycle, Calvörde Formation; Lower Buntsandstein Subgroup) and 
was mentioned to be situated in marine sections at the base of the conodont Hindeodus parvus Zone defining the base of the Triassic. Since then, the Nelben clay pit section became reinvestigated by Scholze (2011) in order to perform thin section-analyses on carbonate microfacies as well as completing studies on the $\delta^{13} \mathrm{C}_{\text {carb }}$ and $\delta^{18} \mathrm{O}_{\text {carb }}$ isotope record with a higher number of samples than previously studied by Korte and Kozur (2005). Preliminary reported results (e.g., Scholze, 2011; Scholze and Schneider, 2013; Scholze et al., 2014) led to conclusions on both partial recrystallization of the oolites and isotope signatures reflecting their diagenetic overprinting.

Previous to the present study, only a small number of Zechstein-Buntsandstein sections in the German part of the Central European Basin were studied for $\delta^{13} \mathrm{C}_{\text {org }}$ isotopes. Firstly, the Nelben clay pit section was only mentioned by Bachmann and Kozur (2004: Fig. 8) and Hansen (2006: Fig. 2) to confine the apparent stratigraphic position of the Permian-Triassic boundary by a distinct minimum in $\delta^{13} \mathrm{Corg}$ at the base of the second small-scale cycle of the Calvörde Formation. Secondly, Hiete (2004) and Hiete et al. (2013) analyzed two sections, the Wulften-1 and Holthusen Z1 drill cores, in northern Germany, which lithostratigraphically range from the lower part of the Zechstein Group to the upper Calvörde Formation (Lower Buntsandstein Subgroup). Variations in $\delta^{13} C_{\text {org }}$ show a shift to isotopically lighter values in the "Bänderschiefer facies" (also called "Banded Shale" or "Banded Shale Facies", upper z7, Upper Fulda Formation; Zechstein Group). Similar shifts at this stratigraphic interval were also recorded in the $\mathrm{Mg} / \mathrm{Al}$ - and $\mathrm{Zn} / \mathrm{Al}$-ratios interpreted as to represent a perennial playa lake rich in isotopically light phytoplankton (Hiete, 2004; Hiete et al., 2013).

\subsection{Magnetostratigraphy}

Most recently, the magnetostratigraphy of the Zechstein Group to Lower Buntsandstein Subgroup was summarized by Menning and Käding (2013) based on various previous studies predominantly from both German (e.g., Szurlies, 2001, 2013; Szurlies et al., 2003) and Polish (e.g., Nawrocki, 1997, 2004; Nawrocki et al., 2003) parts of the Central European Basin. Besides the apparent discrepancies between numbers, names and correlations of magnetic polarity zones of respective previous workers, their studies demonstrated the suitability of the sedimentary rocks of the Zechstein-Buntsandstein transition for their palaeomagnetic processing. According to Szurlies et al. (2003) the Permian-Triassic boundary was approximated within the lower part of a normal polarized magnetozone (called "sn1" by Szurlies et al., 2003) by the last occurrence of the conchostracan Falsisca postera. According to more recent results of Scholze et al. (2016), already the begin of this zone of normal polarization in the Upper Fulda Formation (upper z7; Zechstein Group) corresponds to the range of an Early Triassic assemblage of Palaeolimnadiopsis vilujensis and Euestheria gutta indicating a stratigraphic position of the Permian-Triassic boundary within the Zechstein Group. 


\section{Material and Methods}

\subsection{Major- and trace-element geochemistry}

\subsubsection{Nelben section}

From the abandoned clay pit section at Nelben 206 claystones to fine-grained sandstones each ca. $50 \mathrm{~g}$ were sampled from the base to the top of the section in about $10 \mathrm{~cm}$ vertical sample spaces. The position of samples refers to the profile documentation of Scholze (2011). Samples of weathered or faulted portions have been avoided. The rock preparation and $x$-ray fluorescence (XRF) analyses were realized in the laboratory of the Bundesanstalt für Geowissenschaften und Rohstoffe (Hannover, Germany) following in each detail the procedures described by Hiete et al. (2004) and Hiete et al. (2006). Whole rock samples were pulverized by crushing and grounding (particle size $<40 \mu \mathrm{m}$ ). Of each sample $1 \mathrm{~g}$ was glowed for 10 minutes at $1030^{\circ} \mathrm{C}$ in order to determine the "loss on ignition" (LOI) of easily volatilized ingredients (e.g., water). After that, each sample was glowed for 20 minutes at $1200^{\circ} \mathrm{C}$ in a slewing platinum crucible in order of homogenization. Resulting melt pellets of each sample were processed for XRF analyses of major-oxides and trace-elements by using two wavelength-dispersive x-ray spectrometers. A Philips PW 1480 equipped with chromium tube measured the contents of $\mathrm{K}_{2} \mathrm{O}, \mathrm{CaO}, \mathrm{TiO}_{2}, \mathrm{Cl}$, and $\mathrm{Ba}, \mathrm{Cs}$, Sb, Sc, Sn; Philips PW 2400 equipped with rhodium tube measured $\mathrm{SiO}_{2}, \mathrm{Al}_{2} \mathrm{O}_{3}, \mathrm{Fe}_{2} \mathrm{O}_{3}, \mathrm{MgO}, \mathrm{Na}_{2} \mathrm{O}, \mathrm{MnO}, \mathrm{SO}_{3}, \mathrm{P}_{2} \mathrm{O}_{5}, \mathrm{~F}$, and $\mathrm{As}, \mathrm{Bi}, \mathrm{Ce}, \mathrm{Co}, \mathrm{Cr}, \mathrm{Cu}, \mathrm{Ga}, \mathrm{Hf}$, La, $\mathrm{Mo}, \mathrm{Nb}, \mathrm{Nd}, \mathrm{Ni}, \mathrm{Pb}, \mathrm{Rb}, \mathrm{Sm}, \mathrm{Sr}, \mathrm{Ta}, \mathrm{Th}, \mathrm{U}, \mathrm{V}, \mathrm{W}, \mathrm{Y}, \mathrm{Zn}, \mathrm{Zr}$ (elements $\mathrm{Cl}, \mathrm{SO}_{3}, \mathrm{~F}$, As were measured semi-quantitatively only due to $\mathrm{LOI}$ ).

\subsubsection{Caaschwitz 6/2012 drill core section}

The Caaschwitz 6/2012 drill core is stored in the core store of the Thüringer Landesanstalt für Umwelt und Geologie (TLUG) at the town Niederpöllnitz. In total, 185 samples have been taken from the drill core for major- and trace-element analysis. The vertical sample spaces differ from $50 \mathrm{~cm}$ in the middle Zechstein Group (z4-z6) to $20 \mathrm{~cm}$ in the Fulda Formation ( $z 7$; upper Zechstein Group), and $50 \mathrm{~cm}$ in the Calvörde Formation (Lower Buntsandstein Subgroup). The rock preparation and the measurements were performed by Activation Laboratories Ltd in Ancaster, Canada. Fusion-ICP analysis was used for measurements of major oxides and selected trace elements. Of each sample $0.2 \mathrm{~g}$ were mixed with Lithium Metaborate/Tetraborate and fused in a graphite crucible. The molten mixture is poured into a $5 \%$ nitric acid solution and shaken about 30 minutes until dissolved. This method provided results for $\mathrm{SiO}_{2}, \mathrm{Al}_{2} \mathrm{O}_{3}, \mathrm{Fe}_{2} \mathrm{O}_{3}, \mathrm{MnO}, \mathrm{MgO}, \mathrm{CaO}, \mathrm{Na}_{2} \mathrm{O}, \mathrm{K}_{2} \mathrm{O}, \mathrm{TiO}_{2}, \mathrm{P}_{2} \mathrm{O}_{5}, \mathrm{LOI}$, and $\mathrm{Ba}, \mathrm{Be}, \mathrm{Sr}, \mathrm{V}$, $\mathrm{Y}, \mathrm{Zr}$. INAA portion-analysis was used for content determination of $\mathrm{Au}, \mathrm{As}, \mathrm{Br}, \mathrm{Co}, \mathrm{Cr}, \mathrm{Cs}, \mathrm{Hf}$, $\mathrm{Rb}, \mathrm{Sb}, \mathrm{Sc}, \mathrm{Th}, \mathrm{U}, \mathrm{La}, \mathrm{Ce}, \mathrm{Nd}, \mathrm{Sm}, \mathrm{Eu}, \mathrm{Tb}, \mathrm{Yb}$, Lu. Of each sample $1 \mathrm{~g}$ aliquot was encapsulated in a polyethylene vial and irradiated at a thermal neutron flux of $7 \times 10^{12} \mathrm{n} \mathrm{cm}^{-2} \mathrm{~s}^{-1}$. After a 7day period, to allow Na-24 to decay, the samples were counted on a high purity Ge detector with resolution of better than $1.7 \mathrm{KeV}$ for the $1332 \mathrm{KeV}$ Co-60 photopeak. Total digestion-ICP analysis was used for measurements of base metals and selected trace elements, which 
comprise $\mathrm{Ag}, \mathrm{Bi}, \mathrm{Cd}, \mathrm{Cu}, \mathrm{Ni}, \mathrm{Pb}, \mathrm{S}, \mathrm{Zn}$. Of each sample $0.25 \mathrm{~g}$ were digested with hydrofluoric acid, followed by a mixture of nitric and perchloric acids, and heated to dryness. After dryness was attained, samples were brought back into solution using hydrochloric acid. Samples were analyzed using a Varian Vista ICP.

For the data sets from both the abandoned clay pit section at Nelben and the Caaschwitz $6 / 2012$ drill core section the contents of major-elements measured in weight percentages were recalculated by extracting the LOI. Then the weight percentages were converted into moles, as suggested by Sheldon and Tabor (2009). For trace-elements absolute measured values were used here.

\subsubsection{Inorganic geochemical palaeoclimate proxies (CIA, $\mathrm{ClA}$, $\mathrm{CIA}-\mathrm{K})$}

The "chemical index of alteration" (CIA; Nesbitt and Young, 1982) is defined for fine-grained sedimentary rocks and reflects the degree of chemical weathering. For quantification of the chemical weathering the following equation is used: $\mathrm{ClA}=\left(\mathrm{Al} /\left[\mathrm{Al}+\mathrm{Ca}^{\prime}+\mathrm{K}+\mathrm{Na}\right]\right) * 100$ (Sheldon and Tabor, 2009), which is based on detritic feldspars (attributed in the equation by the Al-, Ca-, K-content) becoming altered through chemical weathering to clay minerals (represented in the equation by the Al-content). In theory, changes in the CIA could serve as indirect indicator for palaeoclimatic conditions as known from various studies on continental deposits of Paleozoic (e.g., Luthardt et al., 2016) or Mesozoic (e.g., Sciscio and Bordy, 2016) age. For this equation the calcium ( $\mathrm{Ca}^{\prime}$ ) is only attributable from silicates (i.e., plagioclase), while non-silicate Calcium (i.e., carbonates) must be subtracted. Since the here analyzed predominantly fine-grained siliciclastics of the Zechstein-Buntsandstein transitions in continental deposits are relatively rich in carbonate- but poor in plagioclase-content, Hiete (2004) defined the alternative palaeoclimatical proxy "CIA without calcium" (ClA*), which is here calculated using the molar masses (Sheldon and Tabor, 2009) for the following equation: $\mathrm{ClA}^{*}=(\mathrm{Al} /[\mathrm{Al}+\mathrm{K}+\mathrm{Na}]) * 100$. Alternatively, the "chemical index minus potassium" (CIA-K) can be used in order to exclude any potentially influences of potassium mobility. The $\mathrm{CIA}-\mathrm{K}$ is known to serve as proxy for palaeoprecipitation conditions of Late Permian to Early Triassic sections (e.g., Thomas et al., 2011; Gastaldo et al., 2014). The CIA-K is calculated by using molar masses in the following equation: $\mathrm{ClA}-\mathrm{K}=(\mathrm{Al} /[\mathrm{Al}+\mathrm{Ca}+\mathrm{Na}]) * 100$ (Sheldon and Tabor, 2009).

\subsection{Organic carbon-isotopes $\left(\delta^{13} \mathrm{C}_{\mathrm{org}, \mathrm{VPDB}}\right)$}

41 samples from the abandoned Nelben clay pit section, 15 samples from the Caaschwitz quarry section at the Galgenberg hill, and 11 samples from the Thale railway cut section were collected in order to initially assess their value for $\delta^{13} \mathrm{C}$ org-isotope analyses. The isotope measurements were performed in the Key Laboratory of Cenozoic Geology and Environment (Institute of Geology and Geophysics, Chinese Academy of Sciences) in Beijing, China. The analytical processing was described by Chen et al. (2014), which is followed here. For $\delta^{13} \mathrm{Corg}^{-}$ 
analyses, all samples were treated with $1 \mathrm{~N} \mathrm{HCl}$ to remove carbonate, then rinsed with distilled water, and dried at $50{ }^{\circ} \mathrm{C}$. All $\delta^{13} \mathrm{C}$ org-analyses were performed with a Flash 1112 elemental analyzer, connected to a Finnigan MAT253 isotope ratio mass spectrometer. The analytical precision is better than $\pm 0.2 \%$. The values are reported relative to the VPDB standard.

\subsection{Carbonate carbon- and oxygen-isotopes $\left(\delta^{13} C_{c a r b, V P D B}, \delta^{18} O_{\text {carb,VPDB }}\right)$}

\subsubsection{Nelben section}

The rock sampling from the abandoned clay pit section at Nelben (12 carbonatic sandstones, 10 oolitic limestones, and one microbialitic limestone) aimed to obtain as much as possible carbonatic samples from the predominantly siliciclastic succession. The rock preparation was realized in the Geological Institute of the TU Bergakademie Freiberg. Whole rock samples of the carbonatic sandstones were crushed and milled to particle size $<40 \mu \mathrm{m}$. Then the carbonate content was measured using the carbonate bomb technique, for what the sample was treated with concentrated $\mathrm{HCl}$ in order to create a measurable $\mathrm{CO}_{2}$ pressure proportional to its $\mathrm{CaCO}_{3}$ content (for details see Müller and Gastner, 1971). The samples of oolitic and microbialitic limestones were manually treated with a Proxxon mortising machine on freshly cut surfaces in order to obtain powder for isotope analyses exclusively from ooids or microbialites, respectively, but not from mixtures with cements. The $\delta^{13} \mathrm{C}_{\text {carb- }}$ and $\delta^{18} \mathrm{O}_{\text {carb- }}$ analyses were performed at the Goethe-University Frankfurt, Germany. The analytical precision is $\pm 0.03 \%$ ofor $\delta^{13} \mathrm{C}_{\text {carb }}$ and $\pm 0.08 \%$ o for $\delta^{18} \mathrm{O}_{\text {carb }}$.

\subsubsection{Heinebach, Thale, and Caaschwitz sections}

Carbonate nodules from the palaeopedogenically overprinted siliciclastics of the sabkha deposits of the Leine Formation to Lower Fulda Formation ( $z 3$ to lower z7; Zechstein Group) were collected from both the Heinebach clay pit section (10 samples) and the Caaschwitz quarry section at the Galgenberg hill (8 samples). From the Thale railway cut section, 27 samples of oolitic limestones were collected from the second to fourth small-scale cycle of the Calvörde Formation (Lower Buntsandstein Subgroup). For pulverization the Proxxon mortising machine was used as described above. The $\delta^{13} \mathrm{C}_{\mathrm{carb}}-, \delta^{18} \mathrm{O}_{\mathrm{carb}}$-analyses were performed in the Isotope Laboratory of the Friedrich-Alexander University (Erlangen, Germany). The carbonate powders were reacted with $100 \%$ phosphoric acid at $70^{\circ} \mathrm{C}$ using a Gasbench II connected to a ThermoFinnigan Five Plus mass spectrometer. All values are reported in \% relative to VPDB. Reproducibility and accuracy was monitored by replicate analysis of laboratory standards and was generally $\leq \pm 0.06 \%$. 


\subsection{Magnetostratigraphy of the Caaschwitz section}

A total of 91 oriented one inch $(2.54 \mathrm{~cm}$ in diameter) cores were collected from the Caaschwitz quarry section at the Galgenberg hill covering $65 \mathrm{~m}$ of the stratigraphic succession. Spacing of individual samples was generally roughly one meter, however, some parts of the profile such as meters 20 to 25 were to friable and could not been sampled. All cores were taken with a portable gasoline driven rock drill and oriented in the field using a standard magnetic compass. Routine paleomagnetic measurements were carried out in the Department of Earth and Environmental Sciences of the Ludwig-Maximilians-University, using a 2G SQUID magnetometer, housed in a magnetically shielded room. All samples were subjected to stepwise thermal demagnetization experiments using an ASC shielded furnace. The results of the demagnetization experiments were visualized and analyzed using the paleomagnetism.org software package (Koymans, 2016). Characteristic directions of the Natural Remanent Magnetization were identified by eye by at least 4 consecutive data points on the orthogonal projection (Zijderveld, 1967) and subsequently determined applying Principal Component Analysis (PCA, Kirschvink, 1980). In addition to standard paleomagnetic procedures, 15 samples were used to determine the Anisotropy of Magnetic Susceptibility (AMS) on an AGICO KLY-2 Kappabridge applying a 15 position measurement scheme (Jelinek, 1977). For the analysis of the anisotropy data, software developed by Tauxe (2010) was used. Hysteresis parameters and Curie Temperatures $\left(T_{c}\right)$ were determined on a Variable Field Translation Balance (VFTB) (Krása et al., 2007) and analyzed after Leonhardt (2005).

\subsection{Palynology of the Caaschwitz section}

Palynological samples (Caa P 1-8) from siltstones of the Caaschwitz quarry section at the Galgenberg hill span the Fulda and Calvörde Formations. All samples were prepared using standard palynological processing techniques, including $\mathrm{HCl}(33 \%)$ and $\mathrm{HF} \mathrm{(73 \% )} \mathrm{treatment}$ for dissolution of carbonates and silicates, and saturated $\mathrm{ZnCl}_{2}$ solution $(\mathrm{D} \approx 2.2 \mathrm{~g} / \mathrm{ml}$ ) for density separation. Residues were sieved at $15 \mu \mathrm{m}$ mesh size. Slides have been mounted in Eukitt, a commercial, resin-based mounting medium. Sedimentary organic matter was studied under a Leica DM2000 transmitted light microscope.

\subsection{Conchostracan biostratigraphy}

Conchostracans provide a biostratigraphic frame work for the Late Permian-Early Triassic transition in continental deposits as known from previous studies (e.g., Kozur and Weems, $2010,2011)$. The conchostracan fauna of the here studied sections and the biostratigraphic implications were recently described in more detail by Scholze et al. (2016). The present study provides new data from the Langenthal Formation (?z2-z7, Zechstein Group), where conchostracans were searched bed-by-bed in the Langenthal BK2/05 drill core section. The 
conchostracan specimens were photographed by using a motor controlled camera image stacking system of the Zeiss Discovery V8 stereomicroscope. For taxonomic determination the methods described by Scholze and Schneider (2015) were used here. The conchostracan specimens are stored in the Hessian Agency for Nature Conservation, Environment and Geology (HLNUG) under the collection number HLUG-45503 to HLUG-45507; the Langenthal BK2/05 drill core is stored in the HLNUG core store at Hünstetten-Limbach.

\section{Results}

\subsection{Caaschwitz 6/2012 drill core section}

\subsubsection{Lithostratigraphy}

The lithological profile of the Caaschwitz 6/2012 drill core section (Fig. 4) is described here for the first time based on profile documentation and sampling for major- and trace-element geochemistry in November 2014. Its lithostratigraphic subdivision corresponds to the neighboring section of the Caaschwitz quarry at the Galgenberg hill, which was previously described by Scholze in Schneider et al. (2014: Fig. 63). The base of the Caaschwitz 6/2012 drill core section composes an about $17 \mathrm{~m}$ thick interval of restricted marine dolomite of the Plattendolomit horizon overlain by grayish colored siltstones of the Upper Leineton horizon (both z3, Leine Formation; Zechstein Group). The overlying 10.80 m thick sabkha deposits of the $z 4-z 6$ (Zechstein Group) of predominantly red colored, fine-grained siliciclastics with centimeter-sized dolomite nodules show overprinting by both haloturbation and formation of palaeosoils (vertisol). In the upper part of this interval lenticular bedding of reddish to grayish colored, fine-grained, few centimeter-thin sandstone lenses frequently occur, while occurrences of up to decimeter-thick grayish silt- to sandstones are restricted to single layers. The overlying Fulda Formation (z7, uppermost Zechstein Group) is divided in two parts, Lower and Upper Fulda Formation.

The $5.80 \mathrm{~m}$ thick Lower Fulda Formation (lower $\mathrm{z7}$ ) consists of partially palaeopedogenic overprinted red siltstones alternating with internal horizontal- to flaser-bedded, predominantly red colored, fine- to middle-grained sandstones. Its base is marked by a sandstone of gray color remarkably contrasting the underlying interval. Evaporitic gypsum blasts as well as single, well-rounded quartz grains occur occasionally, whereby the latter are indicative for wind transport processes through saltation. An about $4 \mathrm{~m}$ thick interval of coarse-grained sandstone and subsequent middle- to coarse-grained sandstones in alternation with siltstones forms the base of the Upper Fulda Formation (upper z7). Its lower boundary is clear and horizontal, while its upper one gradually changes towards about $13 \mathrm{~m}$ thick alternations of brownish to reddish claystones and siltstones with sandstones showing mixtures of millimeter- to centimeter-thick internal lenticular- and flaser-bedding, which prevail up to the top of the Upper Fulda Formation. Occurrences of the conchostracan species Palaeolimnadiopsis vilujensis in laminated clay- to siltstones intercalating with $\mathrm{mm}$ - 
to $\mathrm{cm}$-sized ripples and lenses of fine-grained sandstones of the Upper Fulda Formation (upper z7) were recently reported by Scholze et al. (2016).

The onset of gray and red colored, fine- and coarse-grained sandstone intercalations marks the base of the Calvörde Formation (Lower Buntsandstein Subgroup). The sandstones show predominantly horizontal-, flaser-, or ripple-bedding alternating with predominantly reddish siltstones. Desiccation cracks (Fig. 10D) and load casts as well as siltstone rip-up clasts occur frequently. The Calvörde Formation (Lower Buntsandstein Subgroup) is exposed from its base to the fifth small-scale cycle, whereby respective small-scale cycles are marked at their base by the onset of predominantly gray color and coarse-grained sandstone of decimeter thickness, while fining-ups of each cycle are here not well developed in each small-scale cycle.

\subsubsection{Major- and trace-element geochemistry}

The absolutely measured values of major- and trace-element analyses of the Caaschwitz $6 / 2012$ drill core section are stored in a data repository (see Supplement 1 ). For the majorelement concentrations the measured weight percentages were converted into moles, which are written here as simple element notation (e.g., "Si" instead of " $\mathrm{SiO}_{2}$ "), as suggested by Sheldon and Tabor (2009). Among all results, the curves of $\mathrm{Fe}, \mathrm{K}, \mathrm{Al}, \mathrm{Ca}$, and $\mathrm{Na}$ have been selected for presentation in Figure 4, since they show strongest variations. In particular, these prominent variations were recorded at two levels: Firstly, at the boundary between the marine dolomite (Plattendolomit horizon, Leine Formation, z3) and overlying siliciclastic sabkha deposits (z4-z6, undifferentiated); secondly, at the boundary between the top of the Upper Fulda Formation (upper z7; Zechstein Group) and the base of the overlying Calvörde Formation (Lower Buntsandstein Subgroup). CIA, CIA*, and $\mathrm{CIA}-\mathrm{K}$ proxies on palaeoclimate were calculated from the mol-converted major-element concentration and plotted in Figure 4. In result, the measurements of all samples show multiple excursions. Single peaks of the $\mathrm{ClA}$ and $\mathrm{CIA}-\mathrm{K}$ are negatively correlated to the respective peaks in the curve of the ratio Si/Al, which is expressed by both their relative intensities and the complementary directions of the peaks. The values of the $\mathrm{CIA}^{*}$ range between 53 and 76, with a mean about 65 . The curve of the $\mathrm{CIA}^{*}$ also reflects a negative correlation with the curve of the ratio Si/Al. In agreement to previous studies on the Zechstein-Buntsandstein transition in northern Germany (Hiete, 2004), the ratio Si/Al reflects the ratio sand/clay, and therefore serves as a proxy for the grainsize. Thus, the curves of $\mathrm{CIA}, \mathrm{ClA}^{*}$, and $\mathrm{CIA}-\mathrm{K}$ correlate with the grain sizes of the lithologic profile of the Caaschwitz 6/2012 drill core section.

In order to eliminate the here recorded grain-size effect, samples from sandstones were excluded from the data set prior calculations of $\mathrm{CIA}, \mathrm{CIA}$, and $\mathrm{CIA}-\mathrm{K}$ (see curves "without sandstones" in Fig. 4). This "sandstone correction" results in more constant curves with strongest variation occurring at the transition from the carbonate-rich Plattendolomit horizon ( $z 3$, Leine Formation) to the overlying interval of the siliciclastic-dominated sabkha 
facies (z4-z6, undifferentiated; Zechstein Group), whereby in particular the peaks in the CIA and $\mathrm{ClA}-\mathrm{K}$ curves correspond to variations in carbonate content. Less intensive variations were also recorded in the Upper Fulda Formation (Zechstein Group) (Fig. 4) which result from the above mentioned higher number of samples in this crucial interval in contrast to wider sampling spaces in the interval of the Lower Buntsandstein Subgroup. After sandstone-correction, $\mathrm{CIA}^{*}$ of the Caaschwitz 6/2012 drill core section range about 70 (Fig. 4). Significant changes at the Zechstein-Buntsandstein boundary can neither be observed in the $\mathrm{CIA}^{*}$ curve nor in the curves of $\mathrm{CIA}$ and $\mathrm{CIA}-\mathrm{K}$.

Among the trace elements, both $\mathrm{Cu}$ and $\mathrm{Pb}$ show remarkable peaks of their highest concentrations (Fig. 4) located directly above the top of the Plattendolomit horizon within grayish siltstones of the Upper Leineton horizon ( $z 3$, Leine Formation; Zechstein Group). The $\mathrm{Rb}$ curve shows multiple peaks, whereby the Zechstein-Buntsandstein boundary correlates with a sharply decreasing Rb content (Fig. 4). Both the curves of S and Sr show rather constant values except in the interval of the siliciclastic sabkha deposits ( $z 4-z 6$, undifferentiated) and sabkha to playa deposits of the Fulda Formation (z7), whereby the highest S- and Sr-concentrations were recorded in the Lower Fulda Formation (lower z7; Zechstein Group).

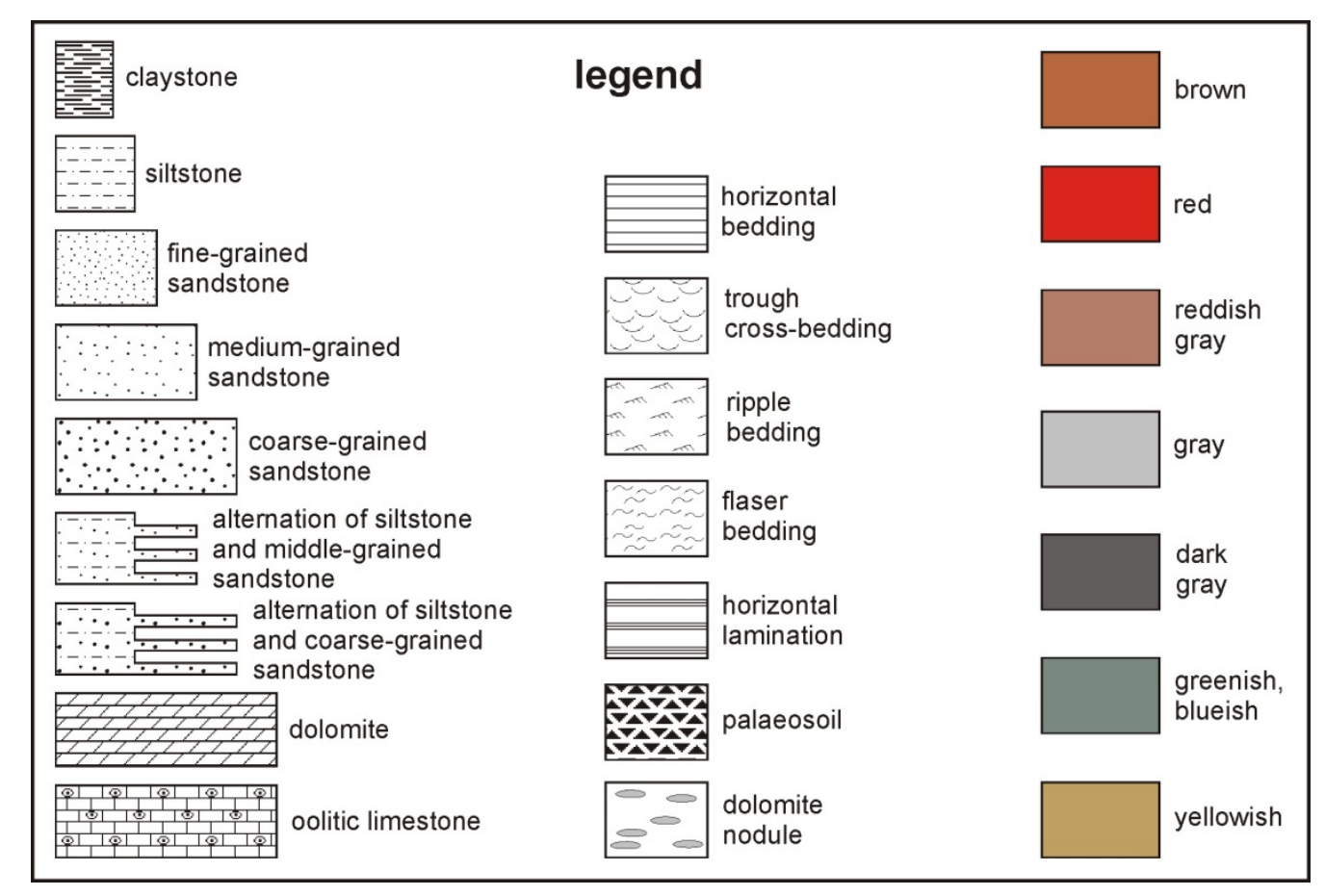

Fig. 3. Legend for the lithologic profiles shown in Figs. 4, 5, 7-9. 


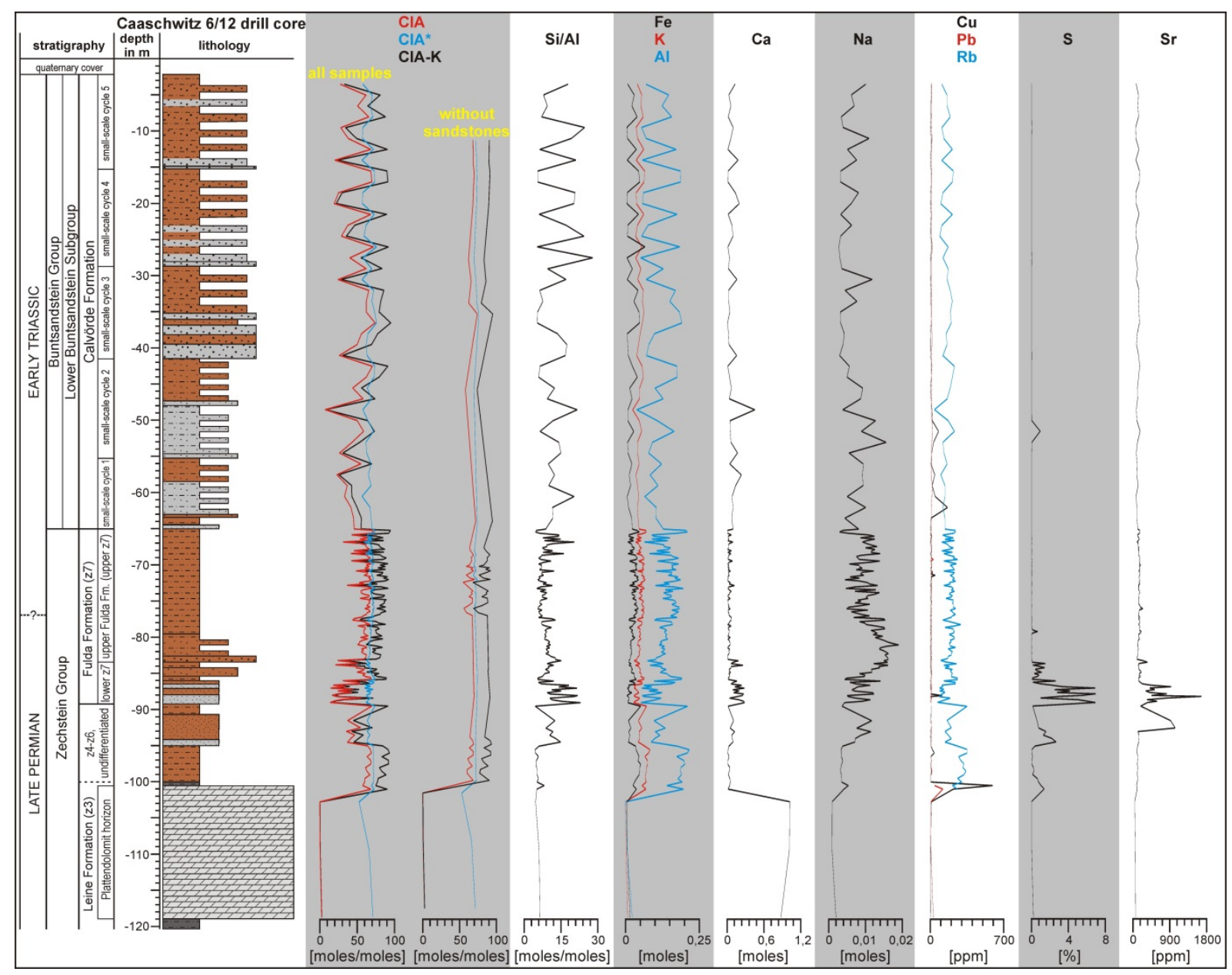

Fig. 4. Lithologic profile of the Caaschwitz 6/2012 drill core section, Thuringia, central Germany; Leine Formation (Zechstein Group) to the middle part of the Calvörde Formation (Lower Buntsandstein Subgroup). Depth is measured below surface. The stratigraphic subdivision is based on the neighboring Caaschwitz quarry section at the Galgenberg hill according to Scholze in Schneider et al. (2014: Fig. 63). The simplified lithologic profile and palaeoclimate proxies $\left(\mathrm{CIA}, \mathrm{Cl} A^{*}, \mathrm{CIA}-\mathrm{K}\right)$ refer to results of the present study. All measurements of major- and trace-elements are listed in Supplement 1.

\subsection{Caaschwitz section}

\subsubsection{Lithostratigraphy}

The about $70 \mathrm{~m}$ thick exposed section of the Caaschwitz quarry at the Galgenberg hill ranges from the Late Permian restricted marine Plattendolomit horizon ( $z 3$, Leine Formation; Zechstein Group) up to fluvial deposits of the second small-scale cycle of the Calvörde Formation (Lower Buntsandstein Subgroup) (Fig. 5). The base of the section comprises $18 \mathrm{~m}$ thick marine-evaporitic dolomites of the Plattendolomit horizon ( $z 3$, Leine Formation; Zechstein Group), which are overlain by greenish and bluish, clayey siltstones to fine sandstones of variable thickness (about 2-3 m) of the Upper Leineton horizon ( $z 3$, Leine 
Formation; Zechstein Group). Above these restricted marine deposits and below the overlying Fulda Formation (z7, Zechstein Group) lies a 9 m-thick interval of sandy siltstones with dolomite nodules of a siliciclastic sabkha facies with palaeopedogenesis (vertisol). In the uppermost part of the Zechstein Group, the Fulda Formation (z7) is subdivided into the Lower Fulda Formation and the Upper Fulda Formation. The Lower Fulda Formation (lower z7) is characterized by a gradual shift towards decreasing intensity of vertisol formation and increasing occurrences of internally laminated and wavy-bedded alternations of claystone, siltstone and sandstone of a sabkha to playa lake facies transition. The Upper Fulda Formation (upper z7) consists, at its base, of a 4.20 m-thick sandstone horizon showing horizontal to irregular wavy internal bedding, millimeter thick clay- to siltstone intercalations, centimeter sized haloturbation, and irregular formed sand patches in which occasional intercalated small scale channels of a fluvial to fluvio-lacustrine depositional environment were observed. These are overlain by an about $12 \mathrm{~m}$-thick interval of predominantly clay- to sandstones with internal mixtures of lenticular- and flaser-bedding, and with ripple marks and desiccation cracks. This interval of the uppermost part of the Upper Fulda Formation (upper z7; uppermost Zechstein Group) is interpreted to represent playa lake deposits pre-dating the Lower Buntsandstein Subgroup (Scholze in Schneider et al., 2014). The directly-overlying Calvörde Formation (base of the Lower Buntsandstein Subgroup) is marked by grayish to reddish, fine- to coarse-grained sandstones containing interfingering with small-scale channels and rip-up clasts indicative for a fluvial facies (Scholze, 2011; Scholze, 2016). The here used position of the lithostratigraphic ZechsteinBuntsandstein boundary corresponds to previous studies of both Schneider in Gebhardt et al. (1995) and Szurlies in Bachmann and Beutler (1998), performed in the directly neighboring Caaschwitz quarry at the Läuseberg hill, as well as more recent work on the profile of the Caaschwitz quarry at the Galgenberg hill (Scholze in Schneider et al., 2014; Scholze et al., 2016). Moreover, the section of the Caaschwitz quarry at the Galgenberg hill was proposed by Scholze et al. (2016) to serve as a regional reference section for the Permian-Triassic boundary in continental deposits. 


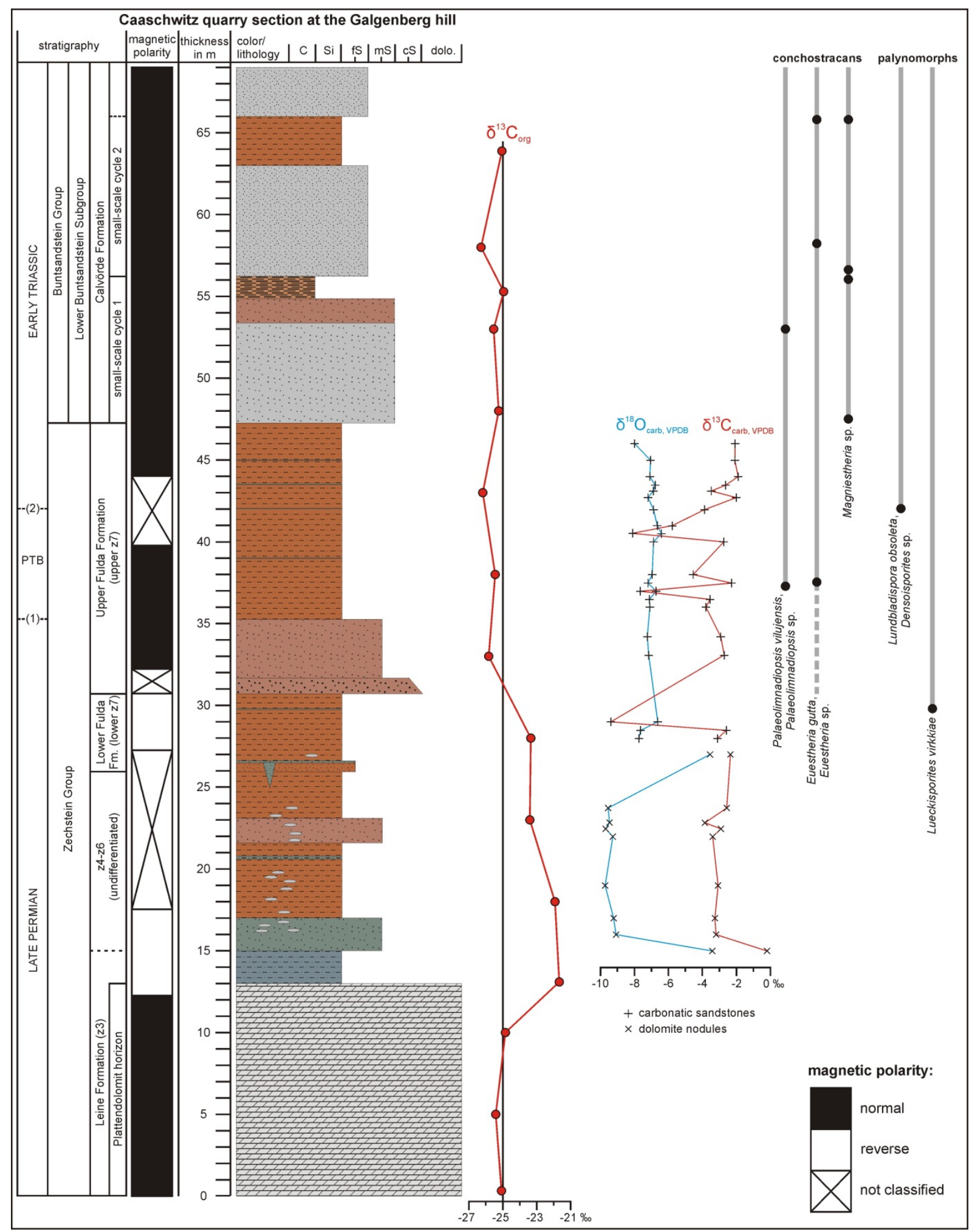

Fig. 5. Lithostratigraphic subdivision and lithologic profile of the Caaschwitz quarry section at the Galgenberg hill, Thuringia, central Germany; Leine Formation (Zechstein Group) to lower part of the Calvörde Formation (Lower Buntsandstein Subgroup). Profile documentation after Scholze (2011), Scholze in Schneider et al. (2014), and data of the present study. Legend see Fig. 3. Measured $\delta^{13} \mathrm{Corg}^{-}, \delta^{18} \mathrm{O}_{\text {carb- }}, \delta^{13} \mathrm{C}_{\mathrm{carb}}$-isotopes (for all values see Supplement 2 and Supplement 3 ) and magnetic polarities refer to results of the present study. Proposed position of the Permian-Triassic boundary (PTB) is based on: (1) first 
occurrence of the Early Triassic Palaeolimnadiopsis vilujensis-Euestheria gutta assemblage of Scholze et al. (2016; about $12 \mathrm{~m}$ below the base of the Zechstein-Buntsandstein boundary in the Caaschwitz 6/2012 drill core section; or (2) the first occurrence of the palynomorphs Lundbladispora obsoleta and Densoisporites sp. of the present study. The stratigraphic range of Euestheria gutta in the Upper Fulda Formation is confirmed by previous studies in the abandoned Caaschwitz quarry at the Läuseberg hill (Kozur and Seidel, 1983a; Kozur and Weems, 2010). The section was suggested by Scholze et al. (2016) to serve as a regional reference profile for the Permian-Triassic boundary in continental deposits.

\subsubsection{Carbonate carbon- and oxygen-isotopes $\left(\delta^{13} \mathrm{C}_{\text {carb,VPDB }}, \delta^{18} \mathrm{O}_{\text {carb,VPDB }}\right)$}

The absolute measured $\delta^{13} \mathrm{C}_{\text {carb }}$ and $\delta^{18} \mathrm{Ocarb}$ values are shown in Supplement 2 . For the middle to upper Zechstein Group (z4-lower $\mathrm{z7}$ ) the samples were obtained from dolomite nodules of the siliciclastic sabkha facies, while the samples from the Upper Fulda Formations (upper z7; Zechstein Group) were obtained from carbonatic cemented sandstone present as $\mathrm{cm}$-thin lenses within clay- to siltstones of the playa lake facies (Fig. 5). The $\delta^{13} \mathrm{C}_{\text {carb }}$ values range from $-9.38 \%$ o to $-0.20 \%$ and for $\delta^{18}$ Ocarb from $-9.72 \%$ o to $-3.42 \%$. The sample of heaviest values of both $\delta^{13} C_{\text {carb }}$ and $\delta^{18}$ Ocarb was recorded in the Upper Leineton horizon (upper z3, Leine Formation; Zechstein Group). The dolomite nodules show strongest variations of the $\delta^{18} \mathrm{O}_{\text {carb }}$ values. Multiple peaks of isotopically light $\delta^{13} \mathrm{C}_{\text {carb }}$ were recorded in the carbonatic sandstones of the Fulda Formation ( $z 7$, Zechstein Group). The isotopically lightest $\delta^{13} \mathrm{C}_{\text {carb }}$ values in the section of the Caaschwitz quarry at the Galgenberg hill were measured in carbonatic sandstones occurring as centimeter-thick intercalations and isolated, lenticular-like ripples in the upper and lower parts of the Fulda Formation (z7; Zechstein Group). In particular, one peak of $-9.38 \%$ occurs about $1.70 \mathrm{~m}$ below the top of the Lower Fulda Formation (lower z7; Fig. 5). Two further peaks of $-7.65 \%$ ond $-8.14 \%$ o occur about $10.20 \mathrm{~m}$ and $6.70 \mathrm{~m}$ below the top of the Upper Fulda Formation (upper z7; Fig. 5).

\subsubsection{Organic carbon-isotopes $\left(\delta^{13} C_{\text {org,VPDB }}\right)$}

The values of $\delta^{13} \mathrm{C}_{\text {org }}$ (see Supplement 3) from the Caaschwitz quarry section at the Galgenberg hill range from $-26.28 \%$ to $-21.67 \%$. The isotopically lightest values were recorded in an interval ranging from the top of the Plattendolomit horizon $(z 3$, Leine Formation; Zechstein Group) up to the Lower Fulda Formation (lower z7; Zechstein Group). Interestingly, this interval (except the dolomite at its base) corresponds to the stratigraphic range of the siliciclastic sabkha deposits which were affected by palaeopedogenesis. In contrast, the isotopically lightest values were recorded in the Upper Fulda Formation (upper z7, Zechstein Group) and the overlying Calvörde Formation (Lower Buntsandstein Subgroup) corresponding to playa-lake and fluvial deposits, respectively, without overprinting by palaeosoils. 


\subsubsection{Palaeomagnetics}

Of the 91 samples taken, 61 samples yielded interpretable results. Stepwise thermal demagnetization experiments allow two identify two components of magnetization which can be separated rather clearly with only minor exceptions (Fig. 6). Component A reaches maximum unlocking temperatures around $500^{\circ} \mathrm{C}$ and points towards north with rather steep and positive inclinations which is interpreted to reflect the direction of the Earth's present day field in the Caaschwitz area. Component $B$ is identified at demagnetization temperatures above $500^{\circ} \mathrm{C}$ and reaches maximum unblocking temperatures of $675^{\circ} \mathrm{C}$, clearly indicating hematite as carrier of this magnetization. This observation is confirmed by a series of rock magnetic experiments yielding Curie temperatures of $675^{\circ} \mathrm{C}$ and hysteresis loops not reaching saturation. Both findings are diagnostic for the dominating presence of hematite. Component $B$ is of mixed polarities and points to the north (south) with positive (negative) inclinations. Only four directions of reversed polarity have been identified which concentrate in the lower part of the section between meters 10 and 32 .

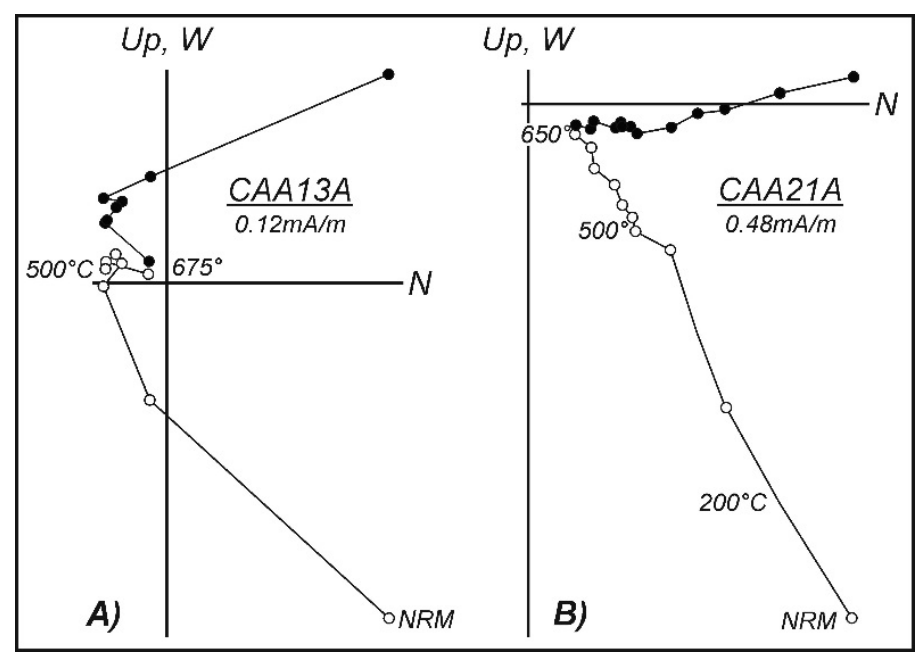

Fig. 6. Thermal demagnetization behavior of two representative samples of inverse $(A)$ and normal (B) polarity from the Caaschwitz quarry section at the Galgenberg hill shown in orthogonal projection (Zijderveld, 1967). Open (closed) symbols are projections onto the vertical (horizontal plane). Also shown is the initial intensity of the Natural Remanent Magnetization.

\subsubsection{Palynology}

Palynology reveals a Late Permian age for the Lower Fulda Formation and lower part of the Upper Fulda Formation and an Early Triassic age for the upper part of the Upper Fulda Formation, based on the occurrence of Lueckisporites virkkiae up to uppermost Lower Fulda 
Formation and Lundbladispora obsoleta and Densoisporites sp. from the upper part of the Upper Fulda Formation. The general poor preservation of sedimentary organic matter across the studied Zechstein-Buntsandstein boundary interval limits palynostratigraphy. However, from the obtained palynological data the position of the Permian-Triassic boundary, according to the palynostratigraphical zonation of Heunisch (1999), is placed in the upper part of the Upper Fulda Formation (Fig. 5). Palynofacies is dominated by opaque phytoclasts. In the Lower Fulda Formation these particles show the highest variability in sizes and shapes, whereas plant debris in the Calvörde Formation is dominated by small, equi-dimensional particles.

\subsection{Heinebach section}

\subsubsection{Lithostratigraphy}

The lithostratigraphic subdivision of the abandoned clay pit at Heinebach was described by Kulick and Paul (1987: p. 99-103) ranging from the Upper Leineton horizon (z3, Leine Formation) to the "Upper Bröckelschiefer" horizon (= upper z7, Upper Fulda Formation) of the Zechstein Group (Fig. 7). The outcrop shows a complex tectonic setting of closely-spaced sub-vertical normal faults (Kulick and Paul, 1987: Fig. 55). The exposure of an about $30 \mathrm{~m}$ thick succession is composed in its lower to middle parts (z6-lower z7, Friesland Formation to Lower Fulda Formation; Zechstein Group) of reddish colored siliciclastics frequently showing palaeopedoturbation of siltstones to fine-grained sandstones and thin layered-like occurrences of dolomite nodules. Cubic or pyramidal halite pseudomorphs (Fig. 10B) occur occasionally, indicating evaporitic conditions. The upper part of the section (basis of the upper z7, Upper Fulda Formation; Zechstein Group) (Fig. 10A) is marked by an interval of horizontally bedded, middle- to fine-grained sandstones with decimeter-thin intercalations of brownish, clayey siltstones. Except for its base, the Upper Fulda Formation, in this section called "Bänderfazies" ("banded facies"; Kulick and Paul, 1987), is now poorly exposed, but formerly cropped out in higher parts of the slope (supposedly at $51^{\circ} 02^{\prime} 00.33^{\prime \prime} \mathrm{N}$, $9^{\circ} 41^{\prime} 13.70^{\prime \prime}$ according to recent field mapping by FS).

\subsubsection{Carbonate carbon- and oxygen-isotopes $\left(\delta^{13} \mathrm{C}_{\text {carb,VPDB }}, \delta^{18} \mathrm{O}_{\text {carb,VPDB }}\right)$}

The results on the measurements of $\delta^{13} \mathrm{C}_{\text {carb }}$ and $\delta^{18} \mathrm{O}_{\text {carb }}$ are given in Supplement 2. The measurements were performed on dolomite nodules obtained from the siliciclastic sabkha deposits ranging in a lithostratigraphic interval from the Friesland Formation ( $z 6)$ to the Lower Fulda Formation (lower z7) of the Zechstein Group. Both the $\delta^{13} \mathrm{C}_{\text {carb }}$ and $\delta^{18} \mathrm{O}_{\text {carb }}$ have strong variations ranging from $-9.69 \%$ o to $-2.16 \%$ and $-9.17 \%$ o to $2.07 \%$, respectively. The lightest $\delta^{13} C_{\text {carb }}$ value of $-9.69 \%$ occurs in the Lower Fulda Formation. Among all sections of the present study, the isotopically most heavy $\delta^{18} \mathrm{O}_{\text {carb }}$ values of $2.07 \%$ and $1.72 \%$ were 
recorded in the uppermost part of the Friesland Formation (z6) and at the basis of the Lower Fulda Formation (lower z7; both Zechstein Group), respectively.

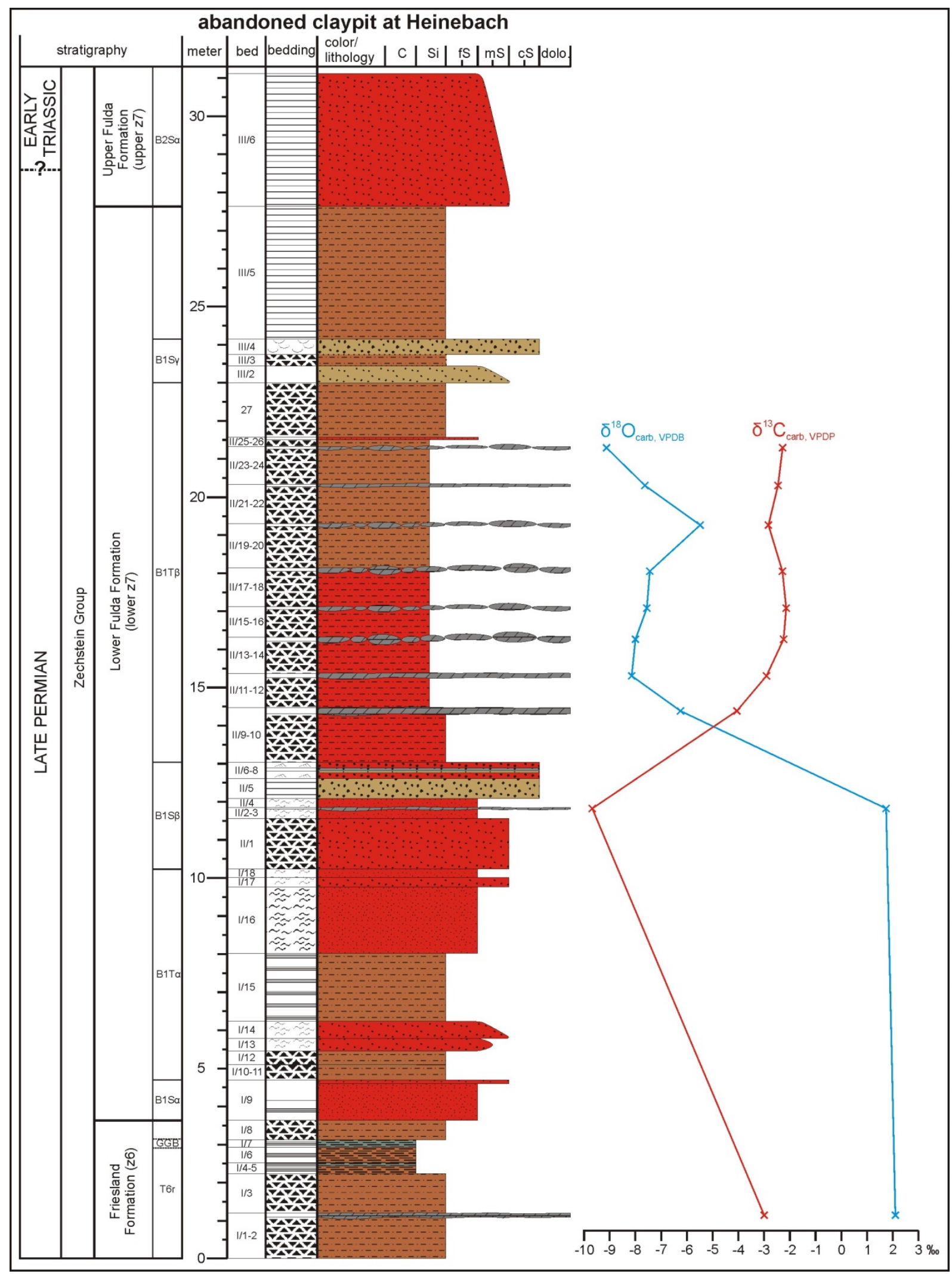


Fig. 7. Lithologic profile of the abandoned clay pit section at Heinebach, Hesse, central Germany; Friesland Formation to Upper Fulda Formation (z6-upper z7; Zechstein Group). Legend see Fig. 3. Measured $\delta^{18} \mathrm{O}_{\text {carb }}, \delta^{13} \mathrm{C}_{\mathrm{carb}}$, and lithologic profile refer to results of the present study (for $\delta^{18} \mathrm{O}_{\mathrm{carb}}$, $\delta^{13} \mathrm{C}_{\mathrm{carb}}$-values see Supplement 2 ; bed numbers according to profile documentation by FS). Lithostratigraphy and subdivision of the formations, e.g. "Graugrüne Grenzbank" horizon (GGB), according to Kulick and Paul (1987).

\subsection{Nelben section}

\subsubsection{Lithostratigraphy}

The abandoned clay pit section at Nelben (also called "quarry near the Saale river bridge at Könnern"; Kozur and Seidel, 1983a) is a key section for the Lower Buntsandstein Subgroup in central Germany known from literature for initial studies on its stratigraphy and local tectonics (e.g., Kunert, 1962), and sedimentary structures (e.g., Hunger, 1950; Roth, 1975). Nowadays, the section exposes an about $22 \mathrm{~m}$ thick interval ranging from the Upper Fulda Formation (upper z7; Zechstein Group) up to the lower part of the second small-scale cycle of the Calvörde Formation (Lower Buntsandstein Subgroup). The mixed carbonatic/siliciclastic section contains two prominent oolitic limestone horizons Alpha 1 and Alpha 2 (also called "Beta 1" and "Beta 2", respectively; e.g., Roth, 1975). A more recent lithostratigraphic subdivision of the section was established by Szurlies (2001) and Bachmann and Kozur (2004), which is followed here except for the position of the ZechsteinBuntsandstein boundary. Szurlies (2001) placed the lithostratigraphic ZechsteinBuntsandstein boundary at a $15 \mathrm{~cm}$ thick, fine-grained sandstone intercalation about $3 \mathrm{~m}$ below the oolite horizon Alpha 1 (Calvörde Formation). More recently, the ZechsteinBuntsandstein boundary was placed by Scholze (2011) directly at the base of the oolite Alpha 1 , which is followed here since it forms a more distinctive lithological boundary.

The lithology mainly consists of reddish and grayish colored, fine-grained siliciclastics with intercalations of the oolitic limestone horizons Alpha 1 and Alpha 2 marking the bases of the first and second small-scale cycles of the Calvörde Formation, respectively. In the siliciclastic intervals occasionally ripple bedding, load casts, and desiccation cracks occur, while the oolites contain fragments of microbial crusts (Scholze, 2011). The deposits are interpreted as a playa facies (e.g., Hauschke and Szurlies, 2006). Recently, occurrences of conchostracans Magniestheria mangaliensis and Euestheria gutta were reported from the Calvörde Formation (Lower Buntsandstein Subgroup) pointing to an Early Triassic age (Scholze et al., 2016). In the predominantly fine-sandy interval of the Upper Fulda Formation (upper z7; Zechstein Group) at the base of this section rarely very large conchostracans (up to $12 \mathrm{~mm}$ in length) occur, which are poorly preserved and, therefore, are taxonomically so far indeterminable. 


\subsubsection{Major- and trace-element geochemistry}

All measured values of major- and trace-elements from the Nelben section are given in the Supplement 4, except for the oolitic limestones of the horizons Alpha 1 and Alpha 2 (Calvörde Formation, Lower Buntsandstein Subgroup), which were not analyzed due to high amount of volatile components of the carbonates unsuited for XRF processing. As shown in the figure of Supplement 5 both the directions and their relative intensities of the peaks in the curves of $\mathrm{CaO}, \mathrm{MgO}, \mathrm{MnO}, \mathrm{Na}_{2} \mathrm{O}, \mathrm{SO}_{3}, \mathrm{Cl}$, and $\mathrm{F}$ positively correlate with each other, which is interpreted to represent enrichment of these major-elements in siliciclastics containing carbonate (i.e., carbonatic cemented sandstones). In contrast, another correlation of peaks is recorded in $\mathrm{SiO}_{2}, \mathrm{TiO}_{2}, \mathrm{Al}_{2} \mathrm{O}_{3}, \mathrm{Fe}_{2} \mathrm{O}_{3}, \mathrm{~K}_{2} \mathrm{O}, \mathrm{P}_{2} \mathrm{O}_{5}$ (see the diagrams in the Supplement 5), which is interpreted to represent predominantly silicatic composition (i.e., clay- and siltstones) instead of carbonate content.

In concordance to the major-element curve of the above mentioned Caaschwitz 6/2012 drill core section (Fig. 4), in the Nelben section both the stratigraphic peaks and their relative intensities in the curves of $\mathrm{CIA}, \mathrm{CI} *$, and $\mathrm{CIA}-\mathrm{K}$ are negatively correlated with the peaks of curve of the ratio Si/Al (Fig. 8). The mean $\mathrm{ClA}^{*}$ range between 70 and 80 . Neither the palaeoclimate proxy $\mathrm{ClA}^{*}$ nor $\mathrm{ClA}$ and $\mathrm{CIA}-\mathrm{K}$ of the Upper Fulda Formation (Zechstein Group) differ from the ranges of the proxies in the overlying Calvörde Formation (Lower Buntsandstein Subgroup). These rather constant values across the Zechstein-Buntsandstein boundary would point to sedimentary deposits apparently unaffected by climatic changes. Among the trace elements, strongest variations were recorded in the Cu curve (Fig. 8). The stratigraphic positions of the two intervals of highest $\mathrm{Cu}$ concentrations correspond to two respective gray colored fine-grained siliciclastic intervals each directly overlying both the oolitic horizons Alpha 1 and Alpha 2 (Calvörde Formation; Lower Buntsandstein Subgroup) (Fig. 8). In contrast, reddish colored intervals of the section continuously show lower Cu concentrations, showing that an enrichment of $\mathrm{Cu}$ is exclusively restricted to grayish colored intervals. 


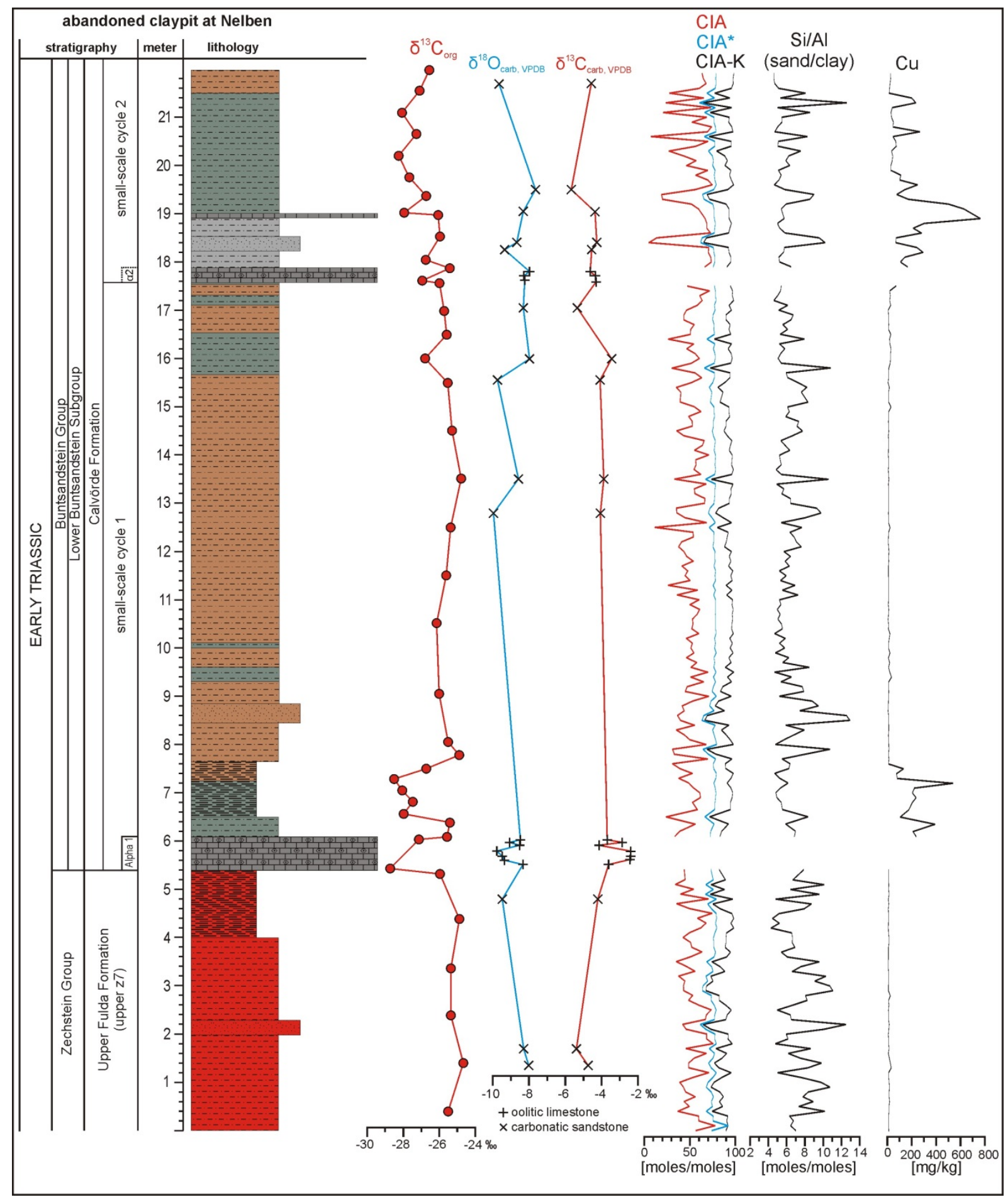

Fig. 8. Lithostratigraphic subdivision and lithologic profile of the Nelben section, SaxonyAnhalt, central Germany; Upper Fulda Formation (Zechstein Group) to lower part of the Calvörde Formation (Lower Buntsandstein Subgroup; Early Triassic, Induan). The lithologic column is simplified from the lithological profile documentation of Scholze (2011) and data of the present study. Legend see Fig. 3. Measured curves of $\delta^{13} \mathrm{C}_{\text {org }^{-}}, \delta^{18} \mathrm{O}_{\text {carb }}, \delta^{13} \mathrm{C}_{\text {carb }}{ }^{-}$ isotopes, palaeoclimate proxies $(\mathrm{CIA}, \mathrm{ClA} * \mathrm{CIA}-\mathrm{K})$, and $\mathrm{Cu}$-trace element measurements refer to results of the present study (for all values see Supplement 2, Supplement 3 , Supplement 4). 


\subsubsection{Carbonate carbon- and oxygen-isotopes $\left(\delta^{13} \mathrm{C}_{\text {carb,VPDB }}, \delta^{18} \mathrm{O}_{\text {carb,VPDB }}\right)$}

The results of $\delta^{13} \mathrm{C}_{\text {carb }}$ and $\delta^{18} \mathrm{O}_{\text {carb }}$ analyses are listed in Supplement 2. The carbonate for the analyses was obtained from both carbonatic cemented sandstones of the Upper Fulda Formation (upper z7) to the Calvörde Formation (Lower Buntsandstein Subgroup) and ooids of the oolitic limestone horizons Alpha 1 and Alpha 2 (Calvörde Formation). The $\delta^{13} \mathrm{C}_{\text {carb }}$ values range from $-5.66 \%$ to $-2.38 \%$ ond the $\delta^{18} \mathrm{O}_{\text {carb }}$ from $-9.96 \%$ o to $-7.65 \%$ o. The $\delta^{13} \mathrm{C}_{\text {carb }}$ and $\delta^{18} \mathrm{O}_{\text {carb }}$ curves (Fig. 8) show multiple excursions in both oolitic limestone and carbonatic sandstone samples. Among the oolitic limestones of the Calvörde Formation in the Nelben section, strongest variations of $\delta^{13} \mathrm{C}_{\text {carb }}$ were recorded in the oolite horizon Alpha 1 ranging between $-4.15 \%$ o to $-2.38 \%$, while the $\delta^{13} \mathrm{C}_{\text {carb }}$ values of the oolite horizon Alpha 2 were isotopically lighter and range from $-4.61 \%$ to $-4.32 \%$.

\subsubsection{Organic carbon-isotopes $\left(\delta^{13} \mathrm{C}_{\mathrm{org}, \mathrm{VPDB}}\right)$}

The $\delta^{13} C_{\text {org }}$ values of the 40 samples from the Nelben section range from $-28.73 \%$ to -24.69 $\%$ (Fig. 8; for the values see Supplement 3). Two intervals of predominantly lighter $\delta^{13} \mathrm{Corg}_{\mathrm{or}}$ values were recorded at the bases of the first and second small-scale cycles of the Calvörde Formation (Lower Buntsandstein Subgroup), each consisting of oolitic limestones and directly overlying greenish gray colored, fine-grained siliciclastics. In contrast, isotopically heavier values show tendencies to be characteristic of reddish colored intervals within the lithologic profile.

\subsection{Thale section}

\subsubsection{Lithostratigraphy}

The about $70 \mathrm{~m}$ thick Thale railway cut section exposes the interval from the second up to the lower part of the sixth small-scale cycle of the Calvörde Formation (Lower Buntsandstein Subgroup). Its lithology and lithostratigraphic subdivision was described in detail by Szurlies (1999), who proposed the profile as a reference section of the lower to middle parts of the Calvörde Formation, since the outcrop well exposes several lithostratigraphic horizons of regional importance such as the "Gray bank" horizon, the oolite horizon Alpha 2, and the oolite horizon Beta 1 (about $90 \mathrm{~cm}$ thickness). Additionally, according to Szurlies (1999) the "Thale horizon" (an interval of about $8.5 \mathrm{~m}$ thick sandstones and oolitic limestones at the base of the third small-scale cycle of the Calvörde Formation) and the "Malachite bank" horizon (a prominent malachite-bearing, gray colored siltstone within the fourth small-scale cycle of the Calvörde Formation) are well exposed in this section. In accordance with the interval of the Calvörde Formation described above from the Nelben section, the mixed 
succession of fine-grained siliciclastics and oolitic limestones is interpreted as playa lake deposits, while sandstones of shallow channels and with cross bedding were interpreted as occasionally sheet floods (e.g., Hauschke and Szurlies, 1998). Desiccation cracks (Figs. 10E-F) were recorded in the lower part of the Thale section. The upper part of the section shows predominantly overprinting of the fine-sandy siltstones by immature vertisols. Besides few single bedding planes containing ostracods, fossils are rare in this section but occurrences of both ichnofossils (Roth, 1975; Hauschke and Szurlies, 1998) and conchostracan species Euestheria gutta (Scholze, 2014) were reported.

\subsubsection{Carbonate carbon- and oxygen-isotopes $\left(\delta^{13} \mathrm{C}_{\text {carb,VPDB }}, \delta^{18} \mathrm{O}_{\text {carb,VPDB }}\right)$}

Supplement 2 contains all the values of $\delta^{13} \mathrm{C}_{\text {carb }}$ and $\delta^{18} \mathrm{O}_{\text {carb }}$ analyses from the Thale section. The isotopically analyzed carbonate was obtained from the ooids of oolitic limestone horizons in an interval ranging from the second to the fourth small-scale cycle of the Calvörde Formation (Lower Buntsandstein Subgroup). The $\delta^{13} \mathrm{C}_{\text {carb }}$ range from $-3.72 \%$ o to $1.34 \%$ o. The $\delta^{18} \mathrm{O}_{\text {carb }}$ shows multiple peaks between $-9.91 \%$ ond $-6.52 \%$ (Fig. 9). The isotopically lightest values were recorded in the "Gray bank horizon" (lower part of the second small-scale cycle; see Fig. 9), while the heaviest $\delta^{13} C_{\text {carb }}$ values were recorded in the oolite horizon Beta 1 at the base of the third small-scale cycle of the Calvörde Formation.

\subsubsection{Organic carbon-isotopes $\left(\delta^{13} \mathrm{Corg}_{\mathrm{oPDB}}\right)$}

The $\delta^{13} \mathrm{C}$ org results on initially measurements of 11 samples from the Thale section vary between $-26.81 \%$ and $-23.73 \%$ (for values see Supplement 3 ). Despite the low number of samples, the first results show pronounced tendencies that isotopically lighter $\delta^{13} \mathrm{C}_{\text {org }}$ values $(<-25 \%$ o) occur in the greenish and grayish colored, mixed carbonatic/siliciclastic interval of the "Gray bank" horizon (second small-scale cycle of the Calvörde Formation; Fig. 9), while isotopically heavier $\delta^{13} C_{\text {org }}$ values (>-25\%) were recorded in the red colored siliciclastics overprinted by immature vertisols in the middle and upper part of the section. A single $\delta^{13} C_{\text {org }}$ shift toward a light value was also recorded in the "Malachit bank" horizon in the middle part of the fourth small-scale cycle of the Calvörde Formation (Lower Buntsandstein Subgroup; Fig. 9), which is also characterized by greenish gray color of fine-grained siliciclastics without overprint by palaeopedogenesis. 


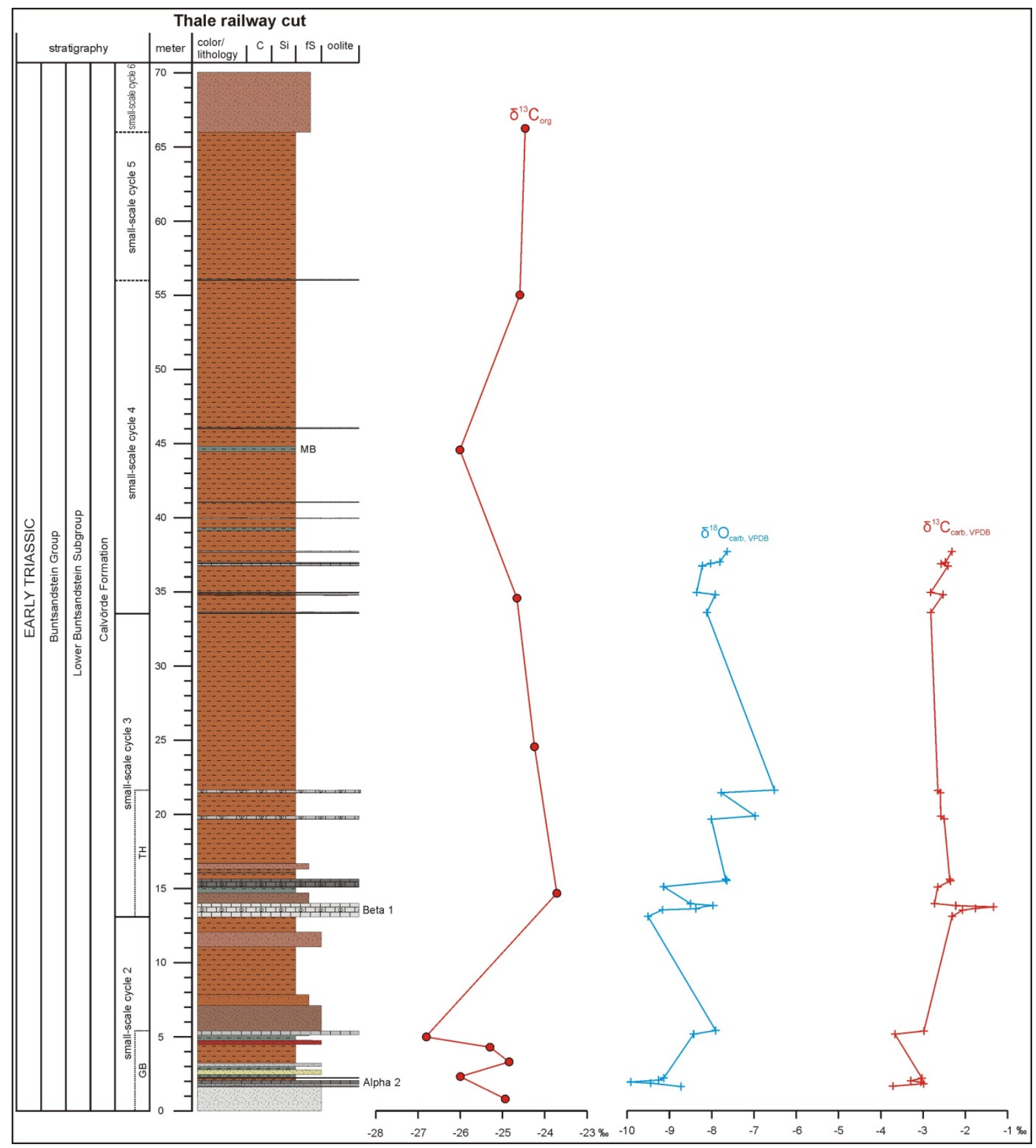

Fig. 9. Simplified lithologic profile of the Thale section, Saxony-Anhalt, central Germany; Calvörde Formation (Lower Buntsandstein Subgroup; Early Triassic, Induan). Legend see Fig.

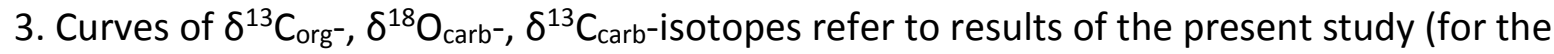
values see Supplement 2 and Supplement 3; sampling and profile documentation by FS in 2011-2016). Small-scale cycles and lithostratigraphic subdivision using "Malachite bank" horizon (MB), and "Thale horizon" (TH) according to Szurlies (2001) and Szurlies et al. (2003). Predominantly gray rock colors indicate the "Gray bank horizon" (GB) at the base of the section. 


\section{Discussion}

\subsection{Major-elements}

Detailed analyses on major- and trace-elements of the Late Permian to Early Triassic continental deposits were previously performed by Hiete (2004) and Hiete et al. (2006) on the Wulften-1 and Holthusen Z1 drill core sections of the Zechstein-Buntsandstein transition in northern Germany. Similar comprehensive analyses were missing from central Germany previous to the present study, besides measurements of selected major-elements by Peter (1983) of the Lower Buntsandstein Subgroup in a drill core section at Gerbitz (Saxony-Anhalt, central Germany). As shown here in the Caaschwitz 6/2012 drill core section (Fig. 4), the curves of $\mathrm{CIA}, \mathrm{ClA}^{*}$, and $\mathrm{CIA}-\mathrm{K}$ correlate with the curve of the ratio $\mathrm{Si} / \mathrm{Al}$. This is in agreement to results of Hiete (2004) implicating variations in $\mathrm{ClA}, \mathrm{Cl}{ }^{*}$, and $\mathrm{CIA}-\mathrm{K}$ are primary affected by the grain size. As shown in Figure 4 the minima values in the $\mathrm{CIA}, \mathrm{CIA}$, and $\mathrm{CIA}-\mathrm{K}$ curves unambiguously negatively correlate with the maxima in the Si/Al curve. Assumed that the ratio $\mathrm{Si} / \mathrm{Al}$ serves as an approximation of the concentration of sandstones (rich in $\mathrm{Si}$ ) and clay minerals (rich in $\mathrm{Al}$ ), respectively, these peaks of high $\mathrm{Si} / \mathrm{Al}$ ratios indicate a high sand/clay ratio. Consequently, variations in the curves $\mathrm{CIA}, \mathrm{CIA}^{*}$, and $\mathrm{CIA}-\mathrm{K}$, directly correlating with the variations in the Si/Al curves as shown in Figure 4, are here interpreted to reflect the grain size of the lithologic profile. Such a correlation is also recorded in the Nelben section (Fig. 8) pointing to high values of $\mathrm{CIA}, \mathrm{ClA}$, and $\mathrm{CIA}-\mathrm{K}$ directly correspond to sandy grain sizes of the respective samples. Therefore, it is argued that $\mathrm{CIA}, \mathrm{CI}{ }^{*}$, or $\mathrm{CIA}-\mathrm{K}$ are unsuitable as proxies for palaeoclimatical conditions of the here studied Zechstein-Buntsandstein transition, because variations of $\mathrm{CIA}, \mathrm{CI}{ }^{*}$, or $\mathrm{CIA}-\mathrm{K}$ in both the Caaschwitz 6/2012 drill core section and the Nelben section are interpreted to primarily depend on the lithology (i.e., grain size) of the respective samples.

In contrast to the geochemical palaeoclimate proxies ( $\left.\mathrm{ClA}, \mathrm{Cl}{ }^{*}, \mathrm{CIA}-\mathrm{K}\right)$, the lithologies and their lithofacies interpretations infer palaeoclimate changes across the Zechstein-

Buntsandstein boundary. In the Nelben section the presence of oolitic limestones at the base of the Calvörde Formation (Lower Buntsandstein Subgroup) differs in lithofacies from the underlying deposits of the Zechstein Group, which may indicate increased precipitation resulting in more stable lacustrine conditions (e.g., Scholze, 2011). As a further example, the base of the Calvörde Formation (Lower Buntsandstein Subgroup) in the Caaschwitz quarry section at the Galgenberg hill is marked by the sudden occurrence of fine- to coarse-grained fluvial sandstones (e.g., Scholze, 2011; Scholze in Schneider et al., 2014; Scholze, 2016) pointing to changes in the water supply (i.e., changes in precipitation) as well as increased fresh water influx. However, neither in the Caaschwitz 6/2012 drill core section (Fig. 4) nor in the Nelben section (Fig. 8) these palaeoclimate changes were indicated by the $\mathrm{CIA}, \mathrm{CIA}$, or CIA-K. The curves show constant ranges across the Zechstein-Buntsandstein boundary. In order to prevent the above described grain sizes effecting the $\mathrm{CIA}, \mathrm{CI}{ }^{*}$, or $\mathrm{CIA}-\mathrm{K}$ proxies, all samples obtained from sandstones were excluded from the major-element data set of the Caaschwitz 6/2012 drill core (see curves "without sandstone" in Fig. 4). The CIA* (and also 
$\mathrm{CIA}$ and $\mathrm{CIA}-\mathrm{K}$ ) values of the siliciclastic sabkha and playa facies of the Zechstein Group do not significantly differ from the values of the Lower Buntsandstein Subgroup. Minor peaks within the Upper Fulda Formation of the Caaschwitz 6/2012 drill core section (Fig. 4) were recorded due to a higher number of samples in this interval (upper z7; Zechstein Group). Additionally, this may account for the data of the Nelben section, because the $\mathrm{CIA}^{*}$ (and also $\mathrm{ClA}$ and $\mathrm{CIA}-\mathrm{K}$ ) values of the Upper Fulda Formation (upper z7; Zechstein Group) do not significantly differ from the values in the Lower Buntsandstein Subgroup (see Fig. 8). Therefore, these rather constant values across the Zechstein-Buntsandstein boundary should not be misinterpreted as apparent proxy of constant palaeoclimate conditions. In contrast, prominent changes in the depositional sedimentary environments indicate differences in the palaeoclimate between the Zechstein Group and the Lower Buntsandstein Subgroup.

The reason for the $\mathrm{CIA}, \mathrm{CI} *$, or $\mathrm{CIA}-\mathrm{K}$ proxies being less sensitive to palaeoclimate changes in the here studied sections might be best explained by already chemically weathered, preaccumulated Permian siliciclastic debris before its final transport and sedimentation. Late Permian-Early Triassic phases of non-sedimentation, leading to enhanced chemical weathering of the pre-accumulated debris, are documented in the Central European Basin by Early Triassic aeolianites such as occurrences of ventrifacts (e.g., Durand and Bourquin, 2013), aeolian facies architectures like dunes, 'pin-stripe sands' (e.g., Maaß et al., 2010), and single, well rounded, coarse quartz grains as well as patchy distributed, silty to sandy dust (e.g., Hug, 2004). The final Early Triassic transport might be triggered either by tectonic pulses or by changes in palaeoclimate conditions. In result, this may account on already chemically weathered siliciclastics of both the Zechstein Group and the Lower Buntsandstein Subgroup, resulting in the here observed apparently constant CIA-values across both the prominent facies changes at the Lower Fulda Formation-Upper Fulda Formation boundary and the Zechstein-Buntsandstein boundary.

\subsection{Trace-elements}

Grayish colored intervals of fine-grained siliciclastics showing the highest $\mathrm{Cu}$ concentrations may indicate oxygen reduced conditions, under which the concentration on Cu may have been enriched. Certain intervals of highest $\mathrm{Cu}$ concentrations were recorded in both the Zechstein Group and the Lower Buntsandstein Subgroup such as the Upper Leineton horizon (z3; Leine Formation) in the Caaschwitz 6/12 drill core section (Fig. 4) as well as the gray colored interval of fine-grained siliciclastics directly overlying the oolitic limestone horizons Alpha 1 and Alpha 2 in the Calvörde Formation of the Nelben section (Fig. 10C). Moreover, in the Caaschwitz 6/2012 drill core section the Cu peak within the Upper Leineton horizon ( $z 3$, Leine Formation) correlates with the highest concentrations of $\mathrm{Pb}$, which may have also resulted from enrichments under oxygen reduced conditions.

Among the trace elements of the Caaschwitz 6/2012 drill core section, the highest concentrations of both $\mathrm{S}$ and $\mathrm{Sr}$, recorded in the siliciclastic sabkha facies in the interval of 
the middle to upper Zechstein Group (z4 to lower $\mathrm{z7}$ ), are interpreted to represent sabkha flats of elevated salinity associated with the formation of evaporitic minerals such as sulfates (e.g., gypsum, coelestine) and chlorides (e.g., halite). This also corresponds to the interval of the siliciclastic sabkha facies, which is known for the occurrences of both dolomite nodules within palaeopedogenically overprinted fine-grained siliciclastics and haloturbation, e.g., in the Caaschwitz quarry section at the Galgenberg (Scholze in Schneider et al., 2014). 


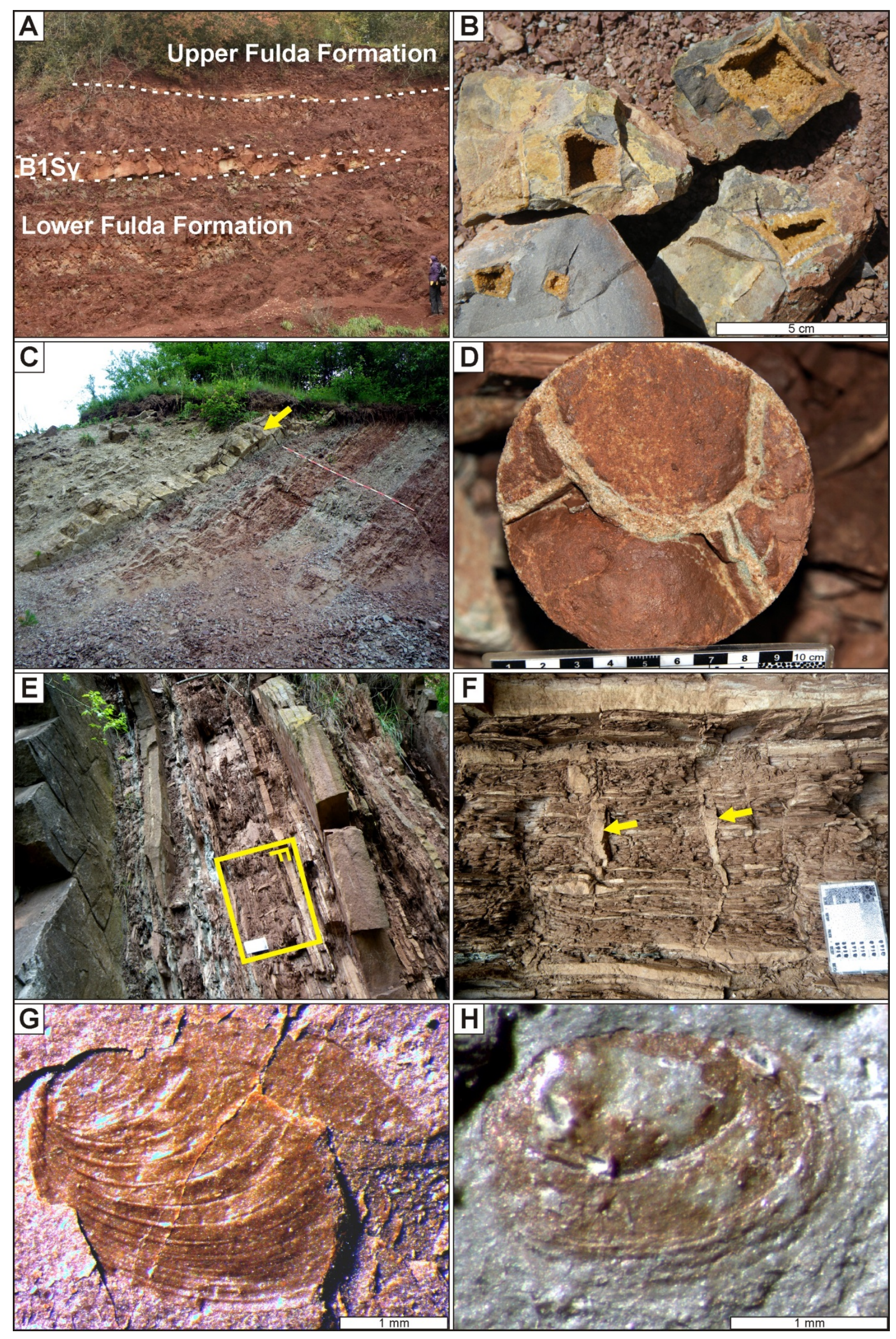


Fig. 10. Examples of outcrop situation, lithology and conchostracans of the studied Zechstein-Lower Buntsandstein profiles in central Germany. A, upper part of the Heinebach section (eastern Hesse, central Germany); Lower and Upper Fulda Formation (lower and upper z7; Zechstein Group); sandstones of the horizon "B1Sץ" after Kulick and Paul (1987). B, internal cubical-shaped pseudomorphs after halite in dolomite nodules used for $\delta^{13} \mathrm{C}_{\text {carb }}$ - and

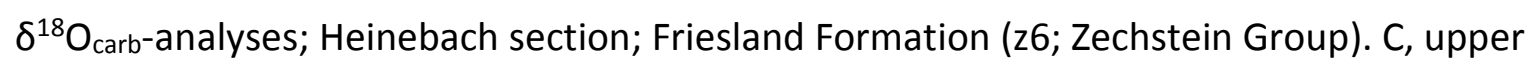
part of the Nelben section (Saxony-Anhalt, central Germany); predominantly gray rock color is characteristic of the so called "Graubankbereich" (Gray bank horizon); oolite horizon Alpha 2 (yellow arrow) marks the base of the second small-scale cycle of the Calvörde Formation (Lower Buntsandstein Subgroup; Early Triassic); D, brownish red siltstone with desiccation cracks of gray colored, middle-grained sandstone; Caaschwitz 6/2012 drill core section, bed 71 , at depth $-36.91 \mathrm{~m}$ to $-36.05 \mathrm{~m} ; 5 \mathrm{~m}$ above the base of the third small-scale cycle of the Calvörde Formation (Lower Buntsandstein Group; Early Triassic). E, dark gray colored oolitic limestone overlain by alternate bedding of bright gray colored, fine-grained sandstone and reddish to greenish clay- and siltstones; Thale section, about $3 \mathrm{~m}$ above the base of the third small-scale cycle of the Calvörde Formation (Lower Buntsandstein Group; Early Triassic). F, detail of $E$ showing desiccation cracks in alternations of claystones to fine-grained sandstones with mixtures of internal flaser- and lenticular-bedding. G, cast of a right conchostracan valve morphologically resembling Pseudestheria ignota (Novozhilov, 1946); Langenthal 2/05 drill core section, at depth -43.90 m, southern Hesse, central Germany; Langenthal Formation (Zechstein Group; Late Permian); specimen HLUG-45503. H, cast of a left valve of Euestheria gutta (Lutkevich, 1937); Thale railway cut section, bed 69; $2.70 \mathrm{~m}$ above base of the third small-scale cycle, Calvörde Formation (Lower Buntsandstein Subgroup; Early Triassic, Induan); specimen FG 660/33/5. C, scale bar 2 m. D-F, length of scale bar $10 \mathrm{~cm}$.

\subsection{Organic and carbonate isotopes}

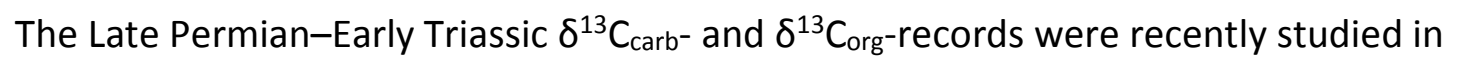
numerous regions, such as marine and continental sections in South China (e.g., Shen et a., 2011; Zhang et al., 2016), Northwest-China (e.g., Cao et al., 2008), Russia (e.g., Aref'ev et al., 2015), Hungary (e.g., Haas et al., 2007), Italy (e.g., Siegert et al., 2011), Greenland (SansonBarrera et al., 2015), Spitsbergen (e.g., Grasby et al., 2015), Canada (e.g., Grasby et al., 2011), Japan (e.g., Takahashi et al., 2010), Iran (e.g., Richoz et al., 2010), Australia (e.g., Thomas et al., 2004), South Africa (e.g., MacLeod et al., 2000; Ward et al., 2005), and Antarctica (e.g., Krull and Retallack, 2000). Isotope shifts to lighter values (in literature often also called "negative peaks" or "negative excursions"), occurring close to the level of the end-Permian mass extinction, were proposed for regional to interregional chemostratigraphic correlations (e.g., Korte and Kozur, 2010). However, it seems that a correlation exclusively based on a certain negative peak should be deliberated critically, 
since the presence of multiple negative peaks were previously reported (e.g., De Wit et al., 2002) from Late Permian-Early Triassic continental deposits.

\subsubsection{Organic carbon-isotopes $\left(\delta^{13} \mathrm{C}_{\mathrm{org}, \mathrm{VPDB}}\right)$}

In the Nelben section, the lightest $\delta^{13} C_{\text {org }}$ value of $-28.73 \%$ was recorded in the oolite horizon Alpha 1 (Calvörde Formation; Lower Buntsandstein Subgroup). In comparison to literature, light $\delta^{13} \mathrm{C}_{\text {org }}$ values of about $-25.5 \%$ o can be generated by Sulfide-oxidizing bacteria, versus more heavy values of about $-22.5 \%$ of eukaryotic algae (Luo et al., 2014 and references therein). As known from marine Permian-Triassic boundary sections in other regions, changes in the relative contributions from eukaryotic algae and chemoautotrophic microbes can affect the $\delta^{13} C_{\text {org }}$ composition of sedimentary organic matter (Luo et al., 2014). Relatively light carbon isotope values from both marine and continental deposits of PermianTriassic boundary sections were previously reported to reflect, e.g., plankton blooms (Dolenec et al., 2000), algal and conchostracan blooms (e.g., Metcalfe et al., 2009), or blooms of cyanobacteria (e.g., Xie and Wang, 2011). In particular, Xie and Wang (2011) detected in marine Permian-Triassic boundary sections at Meishan (South China) and Bulla (Italy) episodic blooms of cyanobacteria associated with both negative excursions of carbon isotope and the horizon of the faunal mass extinction. According to Xie and Wang (2011), volcanism responsible for enhanced atmospheric $\mathrm{CO}_{2}$ levels, global warming, and enhanced Fe influx were proposed to be responsible for these cyanobacteria blooms in the Early Triassic. In analogy, assumed that such consequences of volcanism also affected continental deposits, it may be argued that the relatively light organic carbon isotope values measured here from oolite horizon Alpha 1 of the Nelben section reflect blooms of cyanobacteria. The above described analogy might implicate contemporaneous volcanic activity in the study area. However, regional volcanism during the Early Triassic is so far lacking any lithological evidences (i.e., volcanic ash beds), despite uncertain reports of supposedly volcanic montmorillonite in the Werra Formation (z1, Zechstein Group; Late Permian) of NWGermany (Füchtbauer and Goldschmidt, 1956). However, cyanobacteria blooms responding to volcanism in other regions such as the Siberian Trap basalts of Early Triassic age (e.g., Reichow et al., 2009) should not be excluded, since carbon gas and halocarbon released by contemporaneous placements of Siberian Trap basalt sills in organic-rich deposits were proposed by Svensen et al. (2009) to have affected the atmosphere on a global scale.

The results of the present study proved for the first time the practicability of $\delta^{13} C_{\text {org }}$ measurements of predominantly oxygenated, reddish colored continental siliciclastics of Zechstein-Buntsandstein sections in central Germany. The $\delta^{13} \mathrm{Corg}$ values obtained from all here studied Zechstein-Buntsandstein transition sections range between $-28.73 \%$ and $21.67 \%$ (Fig. 12). The new data indicate that the measured $\delta^{13} \mathrm{Corg}$ values correlate with the lithology of the respective samples. Isotopically lighter values were by trend recorded from both grayish to greenish colored claystones to fine-grained sandstones and grayish oolitic 
limestones, while isotopically heavier values were measured from fine-grained siliciclastics of exclusively reddish color. In total, the $\delta^{13} \mathrm{C}$ org analyses cover a lithostratigraphic range from the Leine Formation (middle part of the Zechstein Group) to the middle part of the Calvörde Formation (Lower Buntsandstein Subgroup). The initial results indicate that $\delta^{13} \mathrm{C}_{\text {org }}$ values heavier than $-25 \%$ were predominantly measured from section intervals affected by palaeopedogenesis (Fig. 12). In particular, these relatively heavy values were recorded in the siliciclastic sabkha facies ranging from the Leine Formation to the lower Fulda Formation (upper z3 to lower z7; Zechstein Group) of the Caaschwitz quarry section at the Galgenberg hill (Fig. 5) as well as in an interval from the third to the sixth small-scale cycle of the Calvörde Formation (Lower Buntsandstein Subgroup) of the Thale section (Fig. 8). Both intervals have in common red colored, pedoturbated, brittle fine-sandy siltstones without distinct internal bedding. Between these two intervals, $\delta^{13} C_{\text {org }}$ values lighter than $-25 \%$ were recorded in the section intervals ranging from the Upper Fulda Formation (upper z7; Zechstein Group) to the second small-scale cycle of the Calvörde Formation (Lower Buntsandstein Subgroup) (Fig. 12). In this stratigraphic interval these sections have in common reddish to grayish colored, well-bedded siliciclastics without occurrences of palaeosoils as observed in the Nelben section (Fig. 8).

The composite range of $\delta^{13} \mathrm{C}_{\text {org }}$ from $-28.73 \%$ to $-21.67 \%$ of all here measured sections lies within the ranges of $\delta^{13} \mathrm{Corg}$ reported from other continental Permian-Triassic boundary sections, e.g., $-34.65 \%$ o to $-22.37 \%$ o recently published by Metcalfe et al. (2009) from the Dalongkou and Lucaogou sections in NW-China. The $\delta^{13} \mathrm{Corg}_{\text {org }}$ measurements recorded multiple isotopically relatively light values instead of a single, distinct negative excursion (Fig. 12). Similar to the results discussed by Metcalfe et al. (2009), a single negative $\delta^{13} C_{\text {org }}$ excursion was not determined and, therefore, cannot be interpreted as representing the negative excursion known from marine Late Permian-Early Triassic sections.

Regionally, the here measured $\delta^{13} C_{\text {org }}$ values fit with the $\delta^{13} C_{\text {org }}$ data from the Wulften- 1 drill core section in northern Germany studied by Hiete et al. (2013), where a $\delta^{13} C_{\text {org }}$ range from $28.4 \%$ to $-21.4 \%$ is documented in an interval of the Ohre Formation ( $z 5$, Zechstein Group; Late Permian) up to the eighth small-scale cycle of the Calvörde Formation (Lower Buntsandstein Subgroup; Early Triassic). For the first time, Hiete et al. (2013 and references therein) recorded in the "Bänderschiefer" horizon of the Upper Fulda Formation (upper z7; Zechstein Group) a $\delta^{13} \mathrm{Corg}$ shift at $-25 \%$ occurring in laminated clay- to sandstones with ripples and desiccation cracks interpreted as deposits of vast sheet floods discharging into ephemeral lakes. There, a shift towards isotopically lighter $\delta^{13} C_{\text {org }}$ values was assumed to be related to the different origin of sedimentary organic matter related to different phytoplankton groups in deposits of both fluvial ephemeral ponds and playa lakes probably resulting from a minor sediment input and better preservation of algae material (Hiete et al., 2013). In concordance to the present study, the recorded shift towards $\delta^{13} C_{\text {org }}$ values less than $-25 \%$ (Fig. 12) can also be interpreted to reflect organic matter of phytoplankton, since similar alternations of clay- to siltstones and fine-grained sandstones of this stratigraphic interval were identified as playa lake deposits (Scholze in Schneider et al., 2014; 
Scholze, 2016; Scholze et al., 2016). The isotopically heavier values from the underlying siliciclastic sabkha deposits of the middle to upper Zechstein Group (lithostratigraphically undifferentiated interval $z 4-z 6$ up to the lower $z 7$ in the Caaschwitz quarry section at the Galgenberg hill; Fig. 5), might have been primary caused by a lower content of preserved phytoplanktonic organic matter, due to less developed lacustrine conditions but increased salinity, stronger subaerial exposition, and overprinting by palaeopedogenesis.

A further differentiation between phototrophic eukaryotic algae (including cyanobacteria) and sulfide-oxidizing bacteria ("green sulfur bacteria" according to Luo et al., 2010) may provide possible explanations for the respective shifts towards isotopically lighter $\delta^{13} \mathrm{Corg}_{\text {or }}$ values such as recorded here in the oolite horizon Alpha 1 (Calvörde Formation; Lower Buntsandstein Subgroup) in the Nelben section (Fig. 8). According to Luo et al. (2014 and references therein), isotopically heavier $\delta^{13} C_{\text {org }}$ values refer to phototrophic (eukaryotic) algae (i.e., cyanobacteria), while relatively lighter $\delta^{13} C_{\text {org }}$ values were generated by blooms of microbes such as sulfide-oxidizing bacteria. So far, it can be concluded that there is no consensus whether lighter $\delta^{13} \mathrm{C}_{\text {org }}$ values might be caused by phytoplanktonic organic matter (e.g., Hiete et al., 2013) or organic matter of sulfide-oxidizing bacteria (e.g., Luo et al., 2014). The production and burial of organic matter might be locally influenced by the variable water levels of shallow ephemeral lakes or ponds as indicated by desiccation cracks in the Nelben section (e.g., Szurlies, 2001; Scholze, 2011). These changes might have resulted in pronounced local and temporary fluxes in photic and oxic zones of the playa lakes or ponds. Therefore, chemostratigraphic correlations should be deliberated critically and are here regarded to require further assessment in successive studies including analyses of $\Delta^{13} \mathrm{C}$ $\left(\delta^{13} C_{c a r b}-\delta^{13} C_{o r g}\right)$ and biomarkers. The former could indicate increasing biomass from a bloom of phototrophic green sulfur bacteria (e.g., Riccardi et al., 2007; Kaiho et al., 2009), while the latter was previously successfully used for determination of the respective components of the organic matter (e.g., Xie et al., 2005, 2007; Cao et al., 2009; Jia et al., 2012). It should be stressed that these methods provided comparable data from marine Permian-Triassic boundary sections. It seems worth to apply them in future studies to the continental deposits of the narrow interval from the Upper Fulda Formation (upper z7, Zechstein Group) up to the second small-scale cycle of the Calvörde Formation (Lower Buntsandstein Subgroup) in order to better understand the here recorded $\delta^{13} \mathrm{C}_{\text {org }}$ shifts to lighter values (Fig. 12) prior to attempts of regional to interregional chemostratigraphic correlations.

\subsubsection{Carbonate carbon- and oxygen-isotopes $\left(\delta^{13} \mathrm{C}_{\mathrm{carb}, \mathrm{VPDB}}, \delta^{18} \mathrm{O}_{\text {carb,VPDB }}\right)$}

Among all studied sections, the record of $\delta^{18} \mathrm{O}_{\text {carb }}$ results from both the Zechstein Group and the overlying Lower Buntsandstein Subgroup ranges between $-9.91 \%$ and $2.07 \%$ o showing multiple variations (Fig. 12). Variations in the oxygen isotope values are not confined to certain lithologies. In the Zechstein Group two most heavy $\delta^{18} \mathrm{O}_{\text {carb }}$ values of $2.07 \%$ and $1.72 \%$ occur in the uppermost part of the Friesland Formation (z6) and at the base of the 
lower Fulda Formation (lower z7; both Zechstein Group), respectively, in the Heinebach section, while all other $\delta^{18} \mathrm{O}_{\text {carb }}$ values from this section range between $-9.17 \%$ o to $-5.52 \%$ (Fig. 7). The measured carbonate was obtained from centimeter-small, gray colored, slightly horizontally arranged dolomite nodules. The deviation of these exceptional isotopically heavy values might be best explained by influences through evaporation during the deposition of the sediment under sabkha conditions. The evaporation is clearly indicated by pseudomorphs of dolomite after cubic halite crystals in the inner center of the dolomite nodules (Fig. 11B). Previous studies on lacustrine environments demonstrate that $\delta^{18} \mathrm{O}_{\text {carb }}$ isotopes can be shifted through evaporation towards isotopically heavy values (e.g., Talbot, 1990). This may account for the $\delta^{18} \mathrm{O}_{\text {carb }}$ values of the here analyzed dolomite nodules of the siliciclastic sabkha facies in the Heinebach setion.

More constant $\delta^{18} \mathrm{O}_{\text {carb }}$ values were exclusively measured in two intervals of the Caaschwitz quarry at the Galgenberg hill. Firstly, from dolomite nodules in the sabkha deposits of the Aller to Ohre Formations ( $z 4-z 6$, undifferentiated; Zechstein Group) ranging in a narrow interval from $-9.72 \%$ o to $-9.10 \%$; and secondly, from the carbonatic sandstones of the Upper Fulda Formation (upper z7; Zechstein Group) ranging between -8.01 \%o and -6.45 \%o

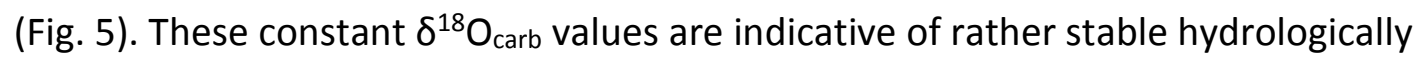
conditions, while $\delta^{13} \mathrm{C}_{\text {carb }}$ values showing larger variations are known from lacustrine carbonates displaying open lake conditions (Talbot, 1990). Among all sections of the Calvörde Formation (Lower Buntsandstein Subgroup) analyzed here for the $\delta^{13} \mathrm{C}_{\text {carb }}$ isotopes, the isotopically heaviest $\delta^{13} C_{\text {carb }}$ value is recorded in the oolite horizon Beta 1 in the Thale section. This peak verifies a previous report by Korte and Kozur (2005), who also recorded the isotopically heaviest value in the oolite horizon Beta 1.

The $\delta^{13} C_{\text {carb }}$ and $\delta^{18} C_{\text {carb }}$ from the Nelben and Thale sections were previously measured by Korte and Kozur (2005) allowing comparison with the results of the present study. The $\delta^{13} C_{\text {carb }}$ values of all measured samples from the Nelben section range from -5.66\%o to $2.38 \%$ o (Fig. 8), and thus have slightly lighter values than those previously measured by Korte and Kozur (2005) ranging from $-4.21 \%$ to $-2.22 \%$. In particular, the $\delta^{13} \mathrm{C}_{\text {carb }}$ values measured here from the oolite horizon Alpha 1 (Fig. 8) differ by both stronger variation and lighter values from the results of Korte and Kozur (2005). The $\delta^{18} \mathrm{O}_{\text {carb }}$ isotopes in the present study from the Nelben section ranging from $-9.96 \%$ to $-7.65 \%$ fit well with the range of $9.74 \%$ o to $-7.17 \%$ measured by Korte and Kozur (2005). This slightly difference in stronger variation of $\delta^{13} \mathrm{C}_{\text {carb }}$ of the present study is interpreted as result of a higher quantity of samples than previously analyzed by Korte and Kozur (2005) from the same section.

Remarkably, a positive correlation between the carbonate oxygen isotopes and the carbonate content (Supplement 2) of carbonate cemented sandstones from the Nelben section, recorded here for the first time (Fig. 11A), indicates that lithology directly reflects the oxygen isotope values. In particular, relatively light $\delta^{18} \mathrm{O}_{\text {carb }}$ values (-9.96 \%o to $-9.34 \%$ o) correlate with samples showing low carbonate content $(<21 \%)$, while respectively heavier $\delta^{18} \mathrm{O}_{\text {carb }}$ values (-8.68\%o to $-7.65 \%$ ) correlate with higher carbonate content (> $27 \%$ ) (Fig. 
11A). Additionally, a diagenetic overprint of oolitic limestones in the Nelben section was previously reported by Scholze (2011) since oolites can show partial recrystallization of both cements and ooids (Fig. 11B). Due to the considerable indications of diagenetic influences, attempts to use the $\delta^{13} \mathrm{C}_{\text {carb }}$ and $\delta^{18} \mathrm{O}_{\text {carb }}$ of both oolites and carbonate cemented sandstones of the Nelben section for correlation of the Permian-Triassic boundary, as suggested by Korte and Kozur (2005), are not suitable.

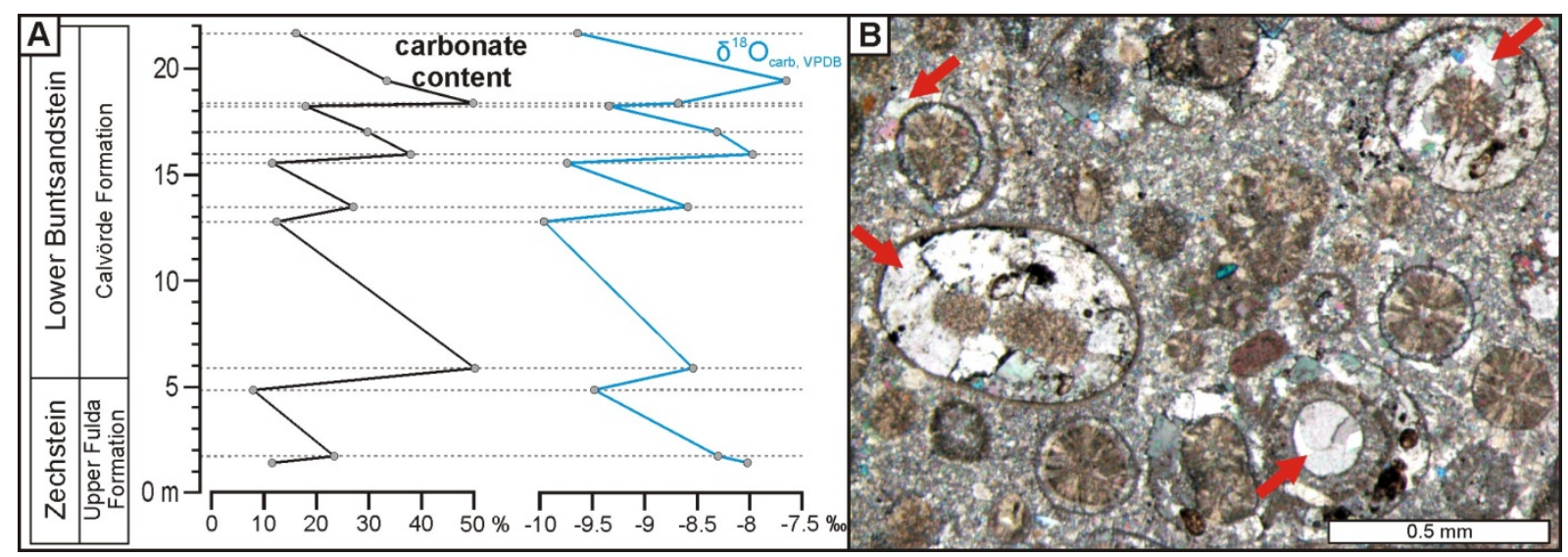

Fig. 11. Indications of diagenetic overprints of carbonate isotopes from the Nelben section, Saxony-Anhalt, central Germany; Upper Fulda Formation to Calvörde Formation (Zechstein Group to Lower Buntsandstein Subgroup; Early Triassic). A, carbonate content and $\delta^{18} \mathrm{O}_{\text {carb }}$ values of carbonatic cemented sandstones showing corresponding curves, peaks and relative intensities of the peaks. B, partially recrystallized oolitic grainstone showing sparry calcite (marked by red arrows) within the ooids; sample from the base of oolite horizon Alpha 2, Calvörde Formation; thin section perpendicular to the bedding plane; cross polarized light.

The phenomenon of carbonate oxygen isotopes correlating with the carbonate content of sandstone, as shown in the Nelben section, is recorded here for the first time in ZechsteinBuntsandstein successions in the study area. Based on comparison with literature from the marine Permian-Triassic boundary section at Meishan in South China, Xie and Wang (2011) mentioned a positive correlation of carbonate content with the $\delta^{13} \mathrm{C}_{\text {carb }}$ from bed 23 to bed 40 , while a positive correlation of carbonate oxygen isotope values with the $\mathrm{MgCO}_{3}$ in bed 27 was described to appear as a local factor. As second example from literature, Bachan et al. (2014) recorded a correlation between carbonate content and $\delta^{18} \mathrm{O}_{\text {carb }}$ and $\delta^{13} \mathrm{C}_{\text {carb }}$ isotopes in a marine marlstone horizon spanning the end-Triassic mass extinction. The correlation with the carbonate content was interpreted by Bachan et al. (2014) to provide evidence that this is tied to the agents of the mass extinction (e.g., sea-level changes, pulse of weathering, ocean acidification). However, compared to the present study, it appears that secondary overprinting by diagenesis cannot be ruled out as a cause of this phenomenon, to date. The latter is further supported by the above mentioned recrystallization observed by 
thin section analysis (Fig. 11B). Consequently, successive studies on correlative carbonate isotopes and carbonate content seem to be necessary for a better understanding of a precise differentiation between local diagenetically factors and global isotopic patterns in order to use carbonate isotopes for interregional chemostratigraphic correlation.

\subsection{Biofacies and biostratigraphy}

Continental deposits of the Lower Buntsandstein Subgroup in central Germany were previously studied for conchostracan biostratigraphy by several workers (e.g., Kozur and Seidel, 1983a; Bachmann and Kozur, 2004; Kozur and Weems, 2010, 2011). More recently, the taxonomy of conchostracans and implications for their use in biostratigraphy were refined by Scholze et al. (2016). Additionally, a conchostracan biostratigraphic zonation for the continental deposits of Late Carboniferous to Early Triassic age and the link to the Global Standard Time Scale was proposed by Schneider and Scholze (in press) including discussions of the conchostracan faunas used for determination of the position of the Permian-Triassic boundary in continental deposits. So far, the playa facies with more stable lacustrine conditions in the Upper Fulda Formation (upper z7; Zechstein Group) can be linked with the first occurrence date (FOD) of an Early Triassic Palaeolimnadiopsis vilujensis and Euestheria gutta assemblage (Scholze et al., 2016). However, further occurrences of conchostracans in the siliciclastic deposits of the Zechstein Group are so far unknown, except for some specimens illustrated by Malzahn (1957) from the Werra Formation (z1; Zechstein Group) and newly collected material from the Langenthal Formation (?z2-z7; Zechstein Group) (Fig. 10G). The latter was found in laminated, red siltstones from the Langenthal 2/05 drill core section (southern Hesse, Germany) at a depth of $-43.90 \mathrm{~m}$. In particular, the material was obtained from the "Schieferletten" interval of the Langenthal Formation, which contains besides Conchostraca also Schizodus-like bivalves and invertebrate burrows (Hug and Vero, 2008). Based on the morphology of the conchostracan valve the specimen resembles Pseudestheria ignota (= "Polygrapta ignota" Novozhilov 1946) known to occur in drill core sections at the Khatanga Bay (Nordwik area, Siberia) of Late Permian age (Novozhilov, 1946). The new conchostracans record from the Langenthal Formation is used here as a biostratigraphical significant Pseudestheria ignota interval (Fig. 12) corresponding to a z2-z7 interval of the Zechstein Group. In analogy, the well preserved specimen from the $z 1$ (Werra Formation) illustrated by Malzahn (1957) resembles morphologically Pseudestheria petri (= "Ulugkemia (Ulugkemia) petri" in Novojilov, 1959), which is known to occur in the Southern Cis-Urals of Late Permian age (Goretzki, 2003). This occurrence is used here to determine a preliminary Pseudestheria petri interval comprising roughly the time of the Werra Formation (Fig. 12). To date, these two proposed units, based on rare records of their index species in the siliciclastic sabkha deposits of the Zechstein Group and without precise knowledge of their real stratigraphic ranges, are regarded here preliminarily as informal "intervals" instead of distinct biozones. 
Recently, Sadovnikov $(2015,2016)$ used the conchostracan index species "Falsisca eotriassica" and "Falsisca postera" in the sense of Kozur and Weems $(2010,2011)$ for correlating the continental deposits of the Siberian Trap basalt plateau with Late Permian marine conodont zones. According to Sadovnikov (2015: p. 445) "Falsisca eotriassica" from the Upper Fulda Formation (upper z7, Zechstein Group) corresponds to the conodont zones of Clarkina iranica and C. hauschkei, while "Falsisca postera" from the lower part of the Calvörde Formation (Lower Buntsandstein Subgroup) corresponds to the Clarkina meishanensis-Hindeodus praeparvus and Merrilina ultima-Stepanvites (?) mostleri zones. However, using "Falsisca eotriassica" and "Falsisca postera" as index species of the former conchostracan biostratigraphic zonation scheme of Kozur and Weems $(2010,2011)$ was rejected by Scholze et al. (2016), due to taxonomic problems on both genus and species levels. Moreover, the interval of the Upper Fulda Formation to the lower part of the Calvörde Formation was incorrectly considered by Sadovnikov $(2015,2016)$ to be of Late Permian age, since it corresponds to the range of the Early Triassic Palaeolimnadiopsis vilujensis-Euestheria gutta assemblage (Scholze et al., 2016).

Palynological data from the Caaschwitz quarry section at the Galgenberg hill place the Permian-Triassic boundary in the Upper Fulda Formation (Fig. 5) which is much lower in stratigraphy as previously dated by Ecke (1986), who described the first Triassic palynomorphs from the lower Calvörde Formation at the boundary between oolite horizon Beta 1 and Beta 2, i.e. between the third and fourth small-scale cycle (Fig. 1). Most likely different preservation of organic matter related to different facies accounts for this discrepancy.

In the Caaschwitz section, the gradual change from a sabkha to playa lake environment during the deposition of the Lower Fulda Formation to a fluvial to fluvio-lacustrine depositional environment during the deposition of the Upper Fulda Formation and fluvial environments recorded in the Calvörde Formation is reflected in the palynofacies and explains the different preservation potential of sedimentary organic matter. In the Lower Fulda Formation and Calvörde Formation palynomorphs are poorly preserved, palynofacies is dominated by opaque phytoclasts. In the Lower Fulda Formation phytoclasts show a high variability in sizes and shapes characteristic of shallow standing water bodies (Tyson, 1995), whereas plant debris in the Calvörde Formation is dominated by small, equi-dimensional particles, characteristic of fluvial deposits with highly fragmented organic matter, due to transport within a hydrodynamic regime of high turbulence (Tyson, 1995). In the fluviolacustrine deposits of the Upper Fulda Formation palynomorph preservation is moderate and phytoclasts are less variable in size and shape than in the underlying Lower Fulda Formation. From the recent results it becomes obvious that sampling on a higher resolution within the Upper Fulda Formation would assist to verify the present position of the PermianTriassic boundary in the upper part of the formation. Furthermore, a slightly lower position of the Permian-Triassic boundary within the lower part of the Upper Fulda Formation as inferred from the first occurrence of Early Triassic conchostracans might be confirmed. 


\subsection{Magnetostratigraphic correlations}

Numerous Permian-Triassic boundary sections in continental deposits suggest a normal polarization at the beginning of the Triassic, such as in the Cis-Urals of Russia (Taylor et al., 2009), South Africa (e.g., Ward et al., 2005), and China (Glen et al., 2009). Within the Central European Basin a normal polarity of the earliest Triassic magnetozone was previously recorded in Germany (e.g., magnetozone "sn1" of Szurlies et al., 2003) and the Netherlands (magnetozone "EV3n" of Szurlies et al., 2012). In continental deposits of Poland the Permian-Triassic boundary was alternatively located in a slightly lower stratigraphic position within a reverse polarity overlain by a normal polarity (e.g., Nawrocki et al., 2003). Therefore, at present, it can be concluded that the Permian-Triassic boundary lies either within a magnetozone of normal polarity or at the boundary between reverse polarization and the normal polarization of the overlaying magnetozone.

Previous magnetostratigraphic measurements of the abandoned Caaschwitz quarry section at the Läuseberg hill (Szurlies, 2001) were now completed with the results of the present study from the neighboring quarry section at the Galgenberg hill. In the Caaschwitz quarry section at the Galgenberg hill the Plattendolomit horizon (z3, Leine Formation; Zechstein Group) has a normal polarity (Fig. 5), which correlates with the normal polarized magnetozone "zny" (Fig. 12) known from the composite magnetostratigraphic zonation of Szurlies et al. (2003). The overlying interval is characterized by both two magnetozones of reverse polarization and two gaps without distinct data on the polarization, whereby the latter are most likely due to the brittle appearance of palaeopedogenically overprinted finegrained siliciclastics less suited for palaeomagnetical laboratory processing. In particular the lithostratigraphically undifferentiated interval z4-z6 (Zechstein Group) is dominated by palaeopedogenic overprinting (vertisol), whereby the characteristic brittle appearance is interpreted as result of swelling and shrinking of clay minerals and the consequently destruction of primary internal sedimentary structures during palaeopedogenesis. Upsection, the here recorded reverse polarization of the Lower Fulda Formation (Fig. 12) correlates with the magnetozone "zrz" of Szurlies et al. (2003), while the Upper Fulda Formation (upper z7) shows predominantly normal polarity. The latter interval of normal polarization ranges up to the top of the section at the second small-scale cycle of the Calvörde Formation (Lower Buntsandstein Subgroup) in the Caaschwitz section (Fig. 5). The onset of this normal polarization verifies a normal polarized magnetozone previously defined as "sn1" by Szurlies et al. (2003) (Fig. 12). 


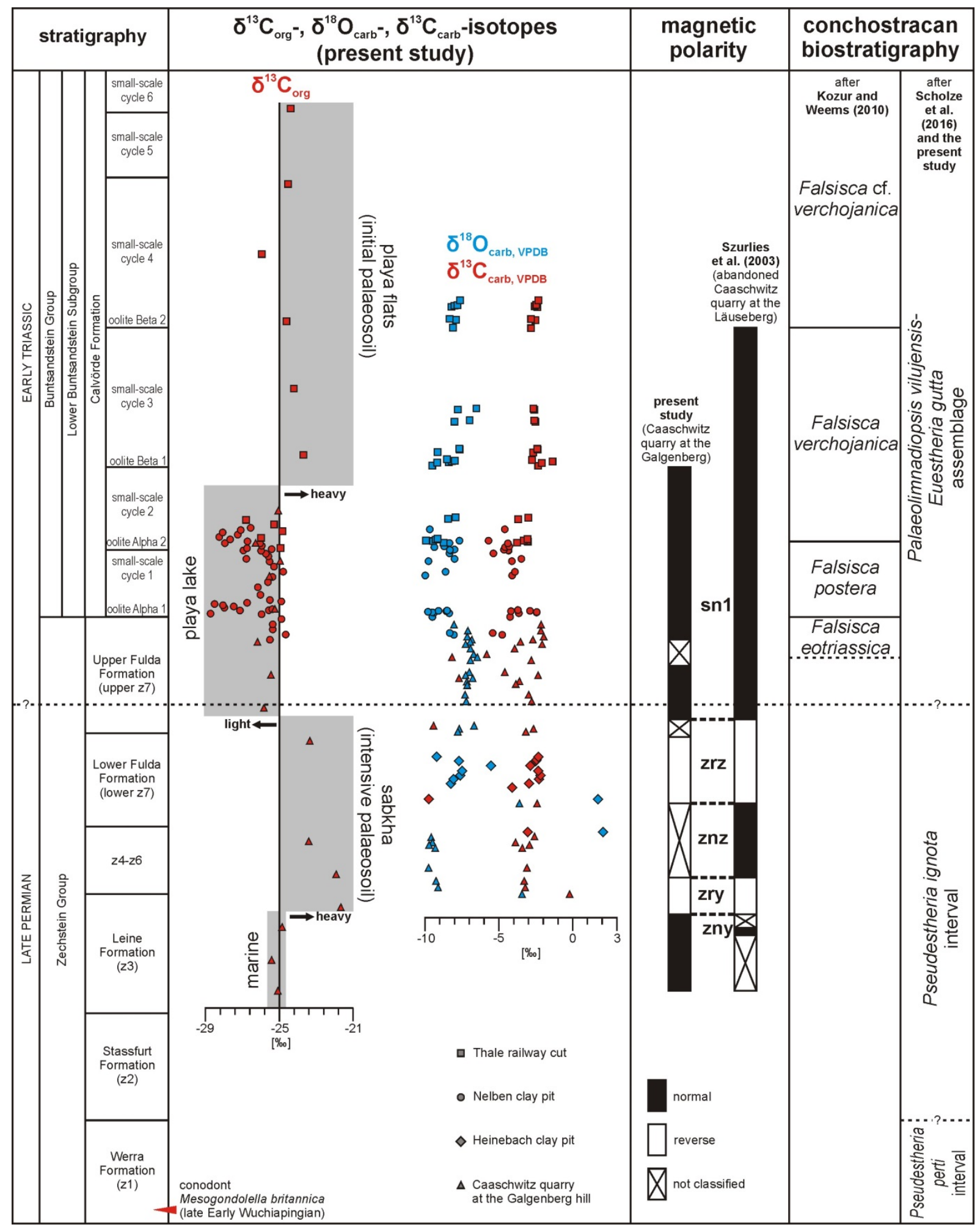

Fig. 12. Multistratigraphic characterization of the Zechstein-Buntsandstein transition in

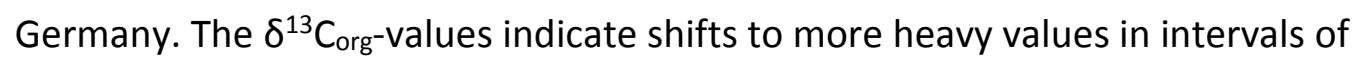
palaeopedogenic overprints. More light $\delta^{13} \mathrm{Corg}_{\mathrm{o}}$-values correspond to the playa lake deposits of the Upper Fulda Formation and lower Calvörde Formation. The magnetic polarity column of the Caaschwitz quarry section at the Galgenberg hill shows a stratigraphic correlation with the magnetozones of the abandoned quarry at the Läuseberg hill according to previous studies of Szurlies (1999) and Szurlies et al. (2003). The conchostracan zonation of Kozur and 
Weems (2010) is compared with the biostratigraphic subdivision of Scholze et al. (2016) and data of the present study using index species of faunas and assemblages. The proposed position of the Permian-Triassic boundary is based on the first occurrence of the Palaeolimnadiopsis vilujensis-Euestheria gutta assemblage and the normal magnetic polarity in the crucial stratigraphic interval. The Early Wuchiapingian biostratigraphic age of the conodont Mesogondolella britannica from the basal Werra Formation (equivalent of the "Kupferschiefer" horizon) is based on Legler and Schneider (2008). Vertical thickness is not to scale.

\section{Conclusions}

The transition from Late Permian restricted marine deposits of the Zechstein Group to Early Triassic continental deposits of the Lower Buntsandstein Subgroup was multistratigraphically studied in the currently best exposed sections in central Germany. The position of the Permian-Triassic boundary is placed within the Upper Fulda Formation (upper z7) of the uppermost Zechstein Group, based on the new multistratigraphic results: (1) the first occurrence date of the Early Triassic Euestheria gutta-Palaeolimnadiopsis vilujensis fauna, (2) records of Late Permian Lueckisporites virkkiae in the Lower Fulda Formation, and Early Triassic Lundbladispora obsoleta and Densoisporites sp. in the Upper Fulda Formation; (3) the first occurrence date of the Euestheria gutta-Palaeolimnadiopsis vilujensis fauna within the base of the normal polarized magnetozone sn1 correlating with the basal Early Triassic of the marine Global Standard Time Scale.

The palaeoclimate proxies calculated from major-element analyses indicate no significant changes neither at the proposed position of the Permian-Triassic boundary within the Upper Fulda Formation nor at the lithostratigraphic Zechstein-Buntsandstein boundary. However, this apparent palaeoclimate stability across the Zechstein-Buntsandstein boundary conflicts with the observed prominent facies changes at the base of the Upper Fulda Formation (Zechstein Group) as well as at the base of the Calvörde Formation (Lower Buntsandstein Subgroup), which are interpreted to reflect changes in palaeoclimate conditions. Consequently, proxies for the palaeoclimate based on major-elements analyses of the continental deposits of the Zechstein-Buntsandstein transition in central Germany should be deliberated critically. In contrast, the results on trace-elements give new insights to a geochemical characterization of the Zechstein-Buntsandstein boundary; i.e., the Rb content shows a pronounced decrease directly at the base of the Calvörde Formation (base of the Lower Buntsandstein Subgroup), which may serve as a geochemical anomaly useful for regional chemostratigraphical correlations.

According to our initial $\delta^{13} \mathrm{C}_{\text {org }}$ analyses on key sections of the Late Permian-Early Triassic Zechstein-Buntsandstein transition in central Germany, lighter $\delta^{13} \mathrm{Corg}$ values are characteristic of playa lake deposits ranging from the upper part of the Upper Fulda Formation (upper z7, Zechstein Group) to the second small-scale cycle of the Calvörde 
Formation (Lower Buntsandstein Subgroup), while palaeosoils from the overlying uppermost part of the second small-scale cycle to the lower part of the sixth small-scale cycle of the Calvörde Formation have heavier $\delta^{13} \mathrm{C}_{\text {org }}$ values. The new results on $\delta^{13} \mathrm{C}_{\text {carb }}$ and $\delta^{18} \mathrm{O}_{\text {carb }}$ of dolomite nodules, carbonate cemented sandstones, oolites and carbon isotopes show multiple excursions. Since the carbonate samples represent a mixture of different carbonate lithologies of the continental Zechstein-Buntsandstein deposits, their use for chemostratigraphic correlation seems to be ambiguous. However, first results on the direct correlation of $\delta^{18} \mathrm{O}_{\text {carb }}$ with the measured carbonate content of certain samples may verify that isotope values reflect local diagenetic characteristics instead of interregional correlative isotope-chemostratigraphical signals.

\section{Acknowledgment}

We thank the Wünschendorfer Dolomitwerk GmbH and the Geological Surveys TLUG and HLNUG for access to the Caaschwitz quarry and the Caaschwitz and Langenthal drill cores. Heinz-Gerd Röhling (LBEG Hannover) and Silke Voigt (University Frankfurt) are thanked for $\mathrm{XRF}$ and isotope measurements of the Nelben section. Andreas Brosig (Freiberg) is thanked for supporting the field work and for fruitful discussions. This paper is a contribution to IGCP 630 ('Permian-Triassic climatic and environmental extremes and biotic response') and to the Nonmarine-Marine Correlation Working Group (NMCG) of the Subcommissions on Carboniferous, Permian and Triassic Stratigraphy. FS and JWS thank the German Research Foundation (DFG grant 'SCHN 408/22-1') for funding. The study was supported by the SinoGerman Center for Research Promotion ('Cooperative Group Project in Late Paleozoic Palaeobiology, Stratigraphy and Geochemistry') and the Russian Government Program ('Competitive Growth of Kazan Federal University').

\section{References}

Aref'ev, M.P., Kuleshov, V.N., Pokrovskii, B.G., Carbon and Oxygen Isotope Composition in Upper Permian-Lower Triassic Terrestrial Carbonates of the East European Platform: A Global Ecological Crisis against the Background of an Unstable Climate. Doklady Earth Sciences 460 (1), 11-15.

Bachan, A., van de Schootbrugge, B., Payne, J.L., 2014. The end-Triassic negative $\delta^{13} \mathrm{C}$ excursion: $\mathrm{A}$ lithologic test. Palaeogeogr. Palaeoclimat. Palaeoecol. 412, 177-186.

Bachmann, G.H., Beutler, G., 1998. Excursion G. The Classic Germanic Triassic in the Southern Part of the Germanic Basin: Stratigraphy, Sedimentary Environments, Cyclic and Sequence Stratigraphy. In: Bachmann, G.H., Beutler, G., Lerche, I. (Eds.), Excursions of the International Symposium on the Epicontinental Triassic, Halle (Saale), September 1998. Hallesches Jahrb. Geowiss. B Beiheft 6, 153194. 
Bachmann, G.H., Kozur, H.W., 2004. The Germanic Triassic: correlations with the international chronostratigraphic scale, numerical ages and Milankovitch cyclicity. Hallesches Jahrb. Geowiss. B 26, 17-62.

Backhaus, E., Hagdorn, H., Heunisch, C., Schulz, E., Biostratigraphische Gliederungsmöglichkeiten des Buntsandstein. In: Deutsche Stratigraphische Kommission, Lepper, H.-G., Röhling, H.-G. (Eds.), Stratigraphie von Deutschland XI. Buntsandstein. Schriftenreihe der Deutschen Gesellschaft für Geowissenschaften 69, pp. 151-164.

Bauer, K., Kustatscher, E., Krings, M., 2013. The ginkgophytes from the German Kupferschiefer (Permian), with considerations on the taxonomic history and use of Baiera and Sphenobaiera. Bulletin of Geosciences 88 (3), 539-556.

Becker, L., Poreda, R.J., Hunt, A.G., Bunch, T.E., Rampino, M., 2001. Impact Event at the PermianTriassic Boundary: Evidence from Extraterrestrial Noble Gases in Fullerenes. Science 291, 1530-1533.

Benton, M.J., Twichett, R.J., 2003. How to kill (almost) all life: the end-Permian extinction event. Trends in Ecol. Evol. 18, 358-365.

Beutler, G., Szulc, J., 1999. Die paläogeographische Entwicklung des Germanischen Beckens in der Trias und die Verbindung zur Tethys. In: Hauschke, N., Wilde, V. (Eds.), Trias - Eine ganz andere Welt. Verlag Dr. Friedrich Pfeil, Munich, pp. 71-80.

Burgess, S. D., Bowring, S., Shen, S.-z., 2014. High-precision timeline for Earth's most severe extinction. PNAS 111, 3316-3321.

Cao, C., Wang, W., Liu, L., Shen, S., Summons, R.E., 2008. Two episodes of ${ }^{13}$ C-depletion in organic carbon in the latest Permian: Evidence from the terrestrial sequences in northern Xinjiang, China. Earth and Planetary Science Letters 270, 251-257.

Cao, C., Love, G.D., Hays, L.E., Wang, W., Shen, S., Summons, R.E., 2009. Biogeochemical evidence for euxinic oceans and ecological disturbance presaging the end-Permian mass extinction event. Earth and Planetary Science Letters 281, 188-201.

Chen, Z., Wang, X., Hu, J., Yang, S., Zhu, M., Dong, X., Tang, Z., Peng, P., Ding, Z., 2014. Structure of the carbon isotope excursion in a high-resolution lacustrine Paleocene-Eocene Thermal Maximum record from central China. Earth and Planetary Science Letters 408, 331-340.

Chen, J., Shen, S.-z., Li, X.-h., Xu, Y.-g., Joachimski, M.M., Bowring, S.A., Erwin, D.H., Yuan, D.-x., Chen, B., Zhang, H., Wang, Y., Cao, C.-q., Zheng, Q.-f., Mu, L., 2015. High-resolution SIMS oxygen isotope analysis on conodont apatite from South China and implications for the end-Permian mass extinction. Palaeogeogr. Palaeoclimat. Palaeoecol. 448, 26-38.

Chu, D., Tong, J., YU, J., Song, H., Tian, L., 2013. The Conchostracan fauna from the Kayitou Formation of western Guizhou, China. Acta Palaeontologica Sinica 52, 265-280.

Clarkson, M.O., Kasemann, S.A., Wood, R.A., Lenton, T.M., Daines, S.J., Richoz, S., Ohnemueller, F., Meixner, A., Poulton, S.W., Tipper, E.T., 2015. Oceanic acidification and the Permo-Triassic mass extinction. Science 348, 229-232. 
Cui, Y., Bercovici, A., Yu, J., Kumpa, L.R., Freeman, K.H., Su, S., Vajda, V., 2015. Carbon cycle perturbation expressed in terrestrial Permian-Triassic boundary sections in South China. Global and Planetary Change. http://dx.doi.org/10.1016/j.gloplacha.2015.10.018

Dette, K., 1930. Ein Wirbeltierrest im Rogenstein. Zeitschrift der Deutschen Geologischen Gesellschaft 81, 494-495.

De Wit, M.J., Ghosh, J.G., de Villiers, S., Rakotosolfo, N., Alexander, J., Tripathi, A., Looy, C., 2002. Multiple Organic Carbon Isotope Reversals across the Permo-Triassic Boundary of Terrestrial Gondwana Sequences: Clues to Extinction Patterns and Delayed Ecosystem Recovery. The Journal of Geology 110, 227-240.

Dolenec, T., Lojen, S., Dolenec, M., 2000. The Permian-Triassic boundary in the Idrijca Valley (Western Slovenia): isotopic fractionation between carbonate and organic carbon at the $\mathrm{P} / \mathrm{Tr}$ transition. Geologija 42, 165-170.

Doornenbal, H., Stevenson, A., 2010. Petroleum Geological Atlas of the Southern Permian Basin Area. EA GE Publications b.v., Houten.

Durand, M., Bourquin, S., 2013. Criteria for the identification of ventifacts in the geological record: A review and new insights. C. R. Geoscience 345, 111-125.

Ecke, H.H., 1986. Palynologie des Zechsteins und Unteren Buntsandsteins im Germanischen Becken. PhD thesis, Georg-August-Universität Göttingen, Gottingen.

Fijałkowska, A., 1995. Palynostratigraphy of the Zechstein in the North Sudetic Trough. Geological Quarterly 39 (2), 207-228.

Füchtbauer, H., Goldschmidt, H., 1956. Ein Zechsteinanhydrit-Profil mit Einlagerungen von Montmorillonit und einer abweichenden Serpentinvarietät. Heidelberger Beiträge zur Mineralogie und Petrographie 5, 187-203.

Gastaldo, R.A., Knight, C.L., Neveling, J., Tabor, N.J., 2014. Latest Permian paleosols from Wapadsberg Pass, South Africa: Implications for Changhsingian climate. GSA Bulletin 126 (5/6), 665-679.

Gebhardt, U., Gaitzsch, B.G., Schneider, J.W., Rössler, R., 1995. XIII International Congress on Carboniferous-Permian (XIII ICC-P) August 28 - September 2, 1995, Kraków, Poland, Supplement, Guide to Excursion A5, Stratigraphy and facies of the Middle European continental Carboniferous and Permian, August 21 - August 27, 1995, Polish Geological Institute, Krakow.

Glen, J.M.G., Nomade, S., Lyons, J.J., Metcalfe, I., Mundil, R., Renne, P.R., 2009. Magnetostratigraphic correlations of Permian-Triassic marine-to-terrestrial sections from China. Journal of Asian Earth Sciences 36, 521-540.

Goretzki, J., 2003. Biostratigraphy of Conchostracans: A Key for the Interregional Correlations of the Continental Palaeozoic and Mesozoic - Computer-aided Pattern Analysis and Shape Statistics to Classify Groups Being Poor in Characteristics. PhD thesis, Technische Universität Bergakademie Freiberg, Freiberg. 
Grasby, S.E., Sanei, H., Beauchamp, B., 2011. Catastrophic dispersion of coal fly ash into oceans during the latest Permian extinction. Nature Geoscience 4, 104-107.

Grasby, S.E., Beauchamp, B., Bond, D.P.G., Wignall, P., Talavera, C., Galloway, J.M., Piepjohn, K., Reinhardt, L., Blomeier, D., 2015. Progressive environmental deterioration in northwestern Pangea leading to the latest Permian extinction. GSA Bulletin 127 (9/10), 1331-1347.

Haas, J., Demény, A., Hips, K., Zajzon, N., Weiszburg, T.G., Sudar, M., Pálfy, J., 2007. Biotic and environmental changes in the Permian-Triassic boundary interval recorded on a western Tethyan ramp in the Bükk Mountains, Hungary. Global and Planetary Change 55, 136-154.

Hansen, J.H., 2006. Stable isotopes of carbon from basaltic rocks and their possible relation to atmospheric isotope excursions. Lithos 92, 105-116.

Hauschke, N., Szurlies, M., 1998. Excursion B. Stratigraphy, Sedimentary Environment and Cyclicity of Buntsandstein and Lower Muschelkalk in the Central Germanic Basin (North of the Harz Mountains). In: Bachmann, G.H., Beutler, G., Lerche, I. (Eds.), Excursions of the International Symposium on the Epicontinental Triassic, Halle (Saale), September 1998. Hallesches Jahrb. Geowiss. B Beiheft 6, 96-98. Hauschke, N., Szurlies, M., 2006. Kontinentale Perm-Trias-Grenze und Buntsandstein nördlich von Halle (Saale) - Fazies, Bio-, Log-, Zyklen- und Magnetostratigraphie (Exkursion M am 22. April 2006). Jber. Mitt. oberrhein. geol. Ver. N. F. 88, 427-452.

Hauschke, N., Wilde, V., 2000. Limulidenreste aus dem Unteren Buntsandstein (Bernburg-Formation) von Beesenlaublingen (Sachsen-Anhalt). Hallesches Jahrb. Geowiss. B 22, 87-90.

Heunisch, C., 1999. Die Bedeutung der Palynologie für Biostratigraphie und Fazies in der Germanischen Trias. In: Hauschke, N., Wilde, V. (Eds.), Trias - Eine ganz andere Welt. Verlag Dr. Friedrich Pfeil, Munich, pp. 207-220.

Hiete, M., 2004. Umweltveränderungen in der Permo-Trias, Geochemische Charakterisierung Zeitreihenanalyse - Modellierung. PhD thesis, Technische Universität Braunschweig, Braunschweig.

Hiete, M., Berner, U., Heunisch, C., Röhling, H.-G., 2006. A high-resolution inorganic geochemical profile across the Zechstein-Buntsandstein boundary in the North German Basin. Z. dt. Ges. Geowiss. $157,77-106$.

Hiete, M., Röhling, H.-G., Heunisch, C., Berner, U., 2013. Facies and climate changes across the Permian-Triassic boundary in the North German Basin: insights from a high-resolution organic carbon isotope record. Geol. Soc., London, Spec. Pub. 376, 549-574.

Hug, N., 2004. Sedimentgenese und Paläogeographie des höheren Zechsteins bis zur Basis des Buntsandsteins in der Hessischen Senke. Geologische Abhandlungen Hessen 113, 1-238.

Hug, N., Vero, G., 2008. Ein vollständiges Zechsteinprofil im südlichen Odenwald: die hydrogeologische Erkundungsbohrung Langenthal BK2/05. Geol. Jb. Hessen 135, 25-45.

Hunger, R., 1950. Großrippeln auf Rogensteinbänken bei Könnern (Saale) und die Frage der Rogensteinbildung. Mitteilungen aus dem Museum für Naturkunde und Vorgeschichte und dem Naturwissenschaftlichen Arbeitskreis 2 (6), 53-63. 
Jelinek, V., 1977. The statistical theory of measuring anisotropy of magnetic susceptibility of rocks and its application. Geophyzika, Brno.

Jia, C., Huang, J., Kershaw, S., Luo, G., Farabegoli, E., Perri, M.C., Chen, L., Bai, X., Xie, S., 2012.

Microbial response to limited nutrients in shallow water immediately after the end-Permian mass extinction. Geobiology 10, 60-71.

Käding, K.-C., 2000. Die Aller-, Ohre-, Friesland- und Fulda-Folge (vormals Bröckelschiefer-Folge) Stratigraphie und Verbreitung des z4 bis z7 im Zechstein-Becken. Kali und Steinsalz 13 (14), 86-96.

Kaiho, K., Chen, Z.Q., Sawada, K., 2009. Possible causes for a negative shift in the stable carbon isotope ratio before, during and after the end-Permian mass extinction in Meishan, South China. Australian Journal of Earth Sciences 56, 799-808.

Kirschvink, J.L., 1980. The least-squares line and plane and the analysis of palaeomagnetic data. Geophysical Journal of The Royal Astronomical Society 62 (3), 699-718.

Knaust, D., Hauschke, N., 2004. Trace fossils versus pseudofossils in Lower Triassic playa deposits, Germany. Palaeogeogr. Palaeoclimat. Palaeoecol. 215, 87-97.

Knaust, D., Hauschke, N., 2005. Living conditions in a Lower Triassic playa system of Central Germany: evidence from ichnofauna and body fossils. Hallesches Jahrb. Geowiss. B Beiheft 19, 95-108.

Korte, C., Kozur, H.W., 2005. Carbon isotope trend in continental lake deposits of uppermost Permian to Lower Olenekian: Germanic Lower Buntsandstein (Calvörde and Bernburg Formations). Hallesches Jahrb. Geowiss. B Beiheft 19, 87-94.

Korte, C., Kozur, H.W., 2010. Carbon-isotope stratigraphy across the Permian-Triassic boundary: A review. Journal of Asian Earth Sciences 39, 215-235.

Kozur, H., 1999. The correlation of the Germanic Buntsandstein and Muschelkalk with the Tethyan scale. Zentralblatt für Geologie und Paläontologie Teil I 1998 (7-8): 701-725.

Kozur, H.W., Bachmann, G.H., 2005. Correlation of the Germanic Triassic with the international scale. Albertiana 32, 21-35.

Kozur, H., Seidel, G., 1983a. Revision der Conchostracen-Faunen des unteren und mittleren Buntsandsteins. Teil I. Z. Geol. Wissenschaft. 11, 295-423.

Kozur, H., Seidel, G., 1983b. Die Biostratigraphie des unteren und mittleren Buntsandsteins des Germanischen Beckens unter besonderer Berücksichtigung der Conchostracen. Teil II zur Revision der Conchostracen-Faunen des unteren und mittleren Buntsandsteins. Z. Geol. Wissenschaft. 11, 429464.

Kozur, H.W., Weems, R.E., 2010. The biostratigraphic importance of conchostracans in the continental Triassic of the northern hemisphere. In: Lucas, S.G. (Ed.), The Triassic Timescale. Geol. Soc., London, Spec. Publ. 334, pp. 315-417. 
Kozur, H.W., Weems, R.E., 2011. Detailed correlation and age of the continental late Changhsingian and earliest Triassic beds: Implications for the role of the Siberian Trap in the Permian-Triassic biotic crisis. Palaeogeogr. Palaeoclimat. Palaeoecol. 308, 22-40.

Koymans, M.R., Langereis, C.G., Pastor-Galan, D., van Hinsbergen, D.J.J., 2016. Paleomagnetism.org: An online multi-platform open source environment for paleomagnetic data analysis. Computers and Geosciences 93, 127-137.

Kraft, J., 2015. Permian-triassic magnetostratigraphy of the section Caaschwitz, Thuringia. BSc thesis, Ludwig-Maximilians-Universität München, Munich.

Krása, D., Petersen, K., Petersen, N., 2007. Variable Field Translation Balance. In: Gubbins, D., Herrero-Bervera, E. (Eds.), Encyclopedia of Geomagnetism and Paleomagnetism. Springer Netherlands, Dordrecht, pp. 977-979.

Krull, E.S., Retallack, G.J., 2000. $\delta^{13} \mathrm{C}$ depth profiles from paleosols across the Permian-Triassic boundary: Evidence for methane release. GSA Bulletin 112 (9), 1459-1472.

Kulick, J., Paul, J., 1987. Zechsteinaufschlüsse in der Hessischen Senke und am westlichen Harzrand. Internationales Symposium Zechstein 1987 Exkursionsführer II, Niedersächsisches Landesamt für Bodenforschung, Hannover.

Kunert, R., 1962. Exkursion 10a Die Halle-Hettstedter Gebirgsbrücke: Methodik der geologischen Zweitkartierung (Meßtischblatt Hettstedt und Könnern). Ber. Geo. Ges. DDR 7 (1), 129-137.

Langbein, R., 1985. Fluvial-Marine Transitional Depositional Environment Influencing the Diagenesis in the Buntsandstein of Thuringia (German Democratic Republic). In: Mader, M. (Ed.), Aspects of fluvial sedimentation in the Lower Triassic Buntsandstein of Europe. Lecture Notes in Earth Sciences 4, 561-590.

Legler, B., Schneider, J.W., 2008. Marine ingressions into the Middle/Late Permian saline lake of the Southern Permian Basin (Rotliegend, Northern Germany) possibly linked to sea-level highstands in the Arctic rift system. Palaeogeogr. Palaeoclimat. Palaeoecol. 267, 102-114.

Legler, B., Gebhardt, U., Schneider, J.W., 2005. Late Permian non-marine-marine transitional profiles in the central Southern Permian Basin, north Germany. Int. J. Earth Sci. (Geol. Rundsch.) 94, 851-862.

Leonhardt, R., 2006. Analyzing rock magnetic measurements: The RockMagAnalyzer 1.0 software, Computers and Geosciences 32 (9), 1420-1431.

Lepper, J., Rambow, D., Röhling, H.-G., 2013. Lithostratigraphie des Buntsandstein in Deutschland. In: Deutsche Stratigraphische Kommission, Lepper, H.-G., Röhling, H.-G. (Eds.), Stratigraphie von Deutschland XI. Buntsandstein. Schriftenreihe der Deutschen Gesellschaft für Geowissenschaften 69, 69-149.

Luo, G., Huang, J., Xie, S., Wignall, P.B., Tang, X., Huang, X., Yin, H., 2010. Relationships between carbon isotope evolution and variation of microbes during the Permian-Triassic transition at Meishan Section, South China. Int. J. Earth. Sci. (Geol. Rundsch.) 99, 775-784. 
Luo, G., Algeo, T.J., Huang, J., Zhou, W., Wang, Y., Yang, H., Richoz, S., Xie, S., 2014. Vertical $\delta^{13} C_{\text {org }}$ gradients record changes in planktonic microbial community composition during the end-Permian mass extinction. Palaeogeogr. Palaeoclimat. Palaeoecol. 396, 119-131.

Luthardt, L., Rößler, R., Schneider, J.W., 2016. Palaeoclimatic and site-specific conditions in the early Permian fossil forest of Chemnitz-Sedimentological, geochemical and palaeobotanical evidence. Palaeogeogr. Palaeoclimat. Palaeoecol. 441, 627-652.

Maaß , K., Voigt, T., Gaupp, R., 2010. Äolische und fluviatile Sedimentation im Unteren Buntsandstein (Calvörde-Formation) Ost-Thüringens. Beitr. Geol. Thüringen N.F. 17, 169-199.

MacLeod, K.G., Smith, R.M.H., Koch, P.L., Ward, P.D., 2000. Timing of mammal-like reptile extinctions across the Permian-Triassic boundary in South Africa. Geology 28 (3), 227-230.

Malzahn, E., 1957. Neue Fossilfunde und vertikale Verbreitung der niederrheinischen Zechsteinfauna in den Bohrungen Kamp 4 und Friedrich Heinrich 57 bei Kamp-Lintfort. Geol. Jb. 73, 91-126.

Menning, M., Käding, K.-C., 2013. Magnetostratigraphie, Zyklostratigraphie, geologische Zeitskala und Nomenklatur des Buntsandstein von Mitteleuropa. In: Deutsche Stratigraphische Kommission, Lepper, H.-G., Röhling, H.-G. (Eds.), Stratigraphie von Deutschland XI. Buntsandstein. Schriftenreihe der Deutschen Gesellschaft für Geowissenschaften 69, pp. 165-212.

Metcalfe, I., Foster, C.B., Afonin, S.A., Nicoll, R.S., Mundil, R., Wang, X., Lucas, S.G., 2009.

Stratigraphy, biostratigraphy and C-isotopes of the Permian-Triassic non-marine sequence at Dalongkou and Lucaogou, Xinjiang Province, China. Journal of Asian Earth Sciences 36, 503-520.

Müller, G., Gastner, M., 1971. The "Karbonat-Bombe", a simple device for the determination of the carbonate content in sediments, soils and other materials. N. Jb. Miner. Mh. 10, 466-469.

Nawrocki, J., 1997. Permian to Early Triassic magnetostratigraphy from the Central European Basin in Poland: Implications on regional and worldwide correlations. Earth and Planetary Science 152, 37-58.

Nawrocki, J., 2004. The Permian-Triassic boundary in the Central European Basin: magnetostratigraphic constraints. Terra Nova 16, 139-145.

Nawrocki, J., Kuleta, M., Zbroja, S., 2003. Buntsandstein magnetostratigraphy from the northern part of the Holy Cross Mountains. Geological Quarterly 47 (3): 253-260.

Nesbitt, H.W., Young, G.M., 1982. Early Proterozoic climates and plate motions inferred from major element chemistry of lutites. Nature $299,715-717$.

Newell, A.J., Sennikov, A.G., Benton, M.J., Molostovskaya, I.I., Golubev, V.K., Minikh, A.V., Minikh, M.G., 2010. Disruption of playa-lacustrine depositional systems at the Permo-Triassic boundary: evidence from Vyazniki and Gorokhovets on the Russian Platform. J. Geol. Soc. 167, 695-716.

Novozhilov, N.I., 1946. Novye Phyllopoda iz permskich i triasovych otlozhenij Nordvik-Chatangskogo rajona [New Phyllopoda from the Permian and Triassic deposits of the Nordwick-Khatanga Region]. Nedra Arktiki 1, 172-202 [In English and Russian]. 
Novojilov, N., 1959. Découverte de Conchostraca (Crustacés) de la famille des Ulugkemiidae dans le Permien supérieur du Pré-Oural. Extrait Du C.R. Sommaire Des Seances De La Societe Geologique De France 1, 8-9.

Paul, J., 1982. Der Untere Buntsandstein des Germanischen Beckens. Geologische Rundschau 71 (3), 795-811.

Paul, J., Peryt, T.M., 2000. Kalkowsky's stromatolites revisited (Lower Triassic Buntsandstein, Harz Mountains, Germany). Palaeogeogr. Palaeoclimat. Palaeoecol. 161, 435-458.

Peter, H., 1983. Zur lithostratigraphisch-chemischen Gliederung der Nordhausen- und BernburgFolge des Buntsandsteins im Raum Bernburg-östliche Subherzyne Senke. Zeitschrift für angewandte Geologie 29 (1), 32-38.

Puff, P., Radzinski, K.-H., 2013. Der Buntsandstein in der Thüringischen Senke. In: Deutsche Stratigraphische Kommission, Lepper, H.-G., Röhling, H.-G. (Eds.), Stratigraphie von Deutschland XI. Buntsandstein. Schriftenreihe der Deutschen Gesellschaft für Geowissenschaften 69, pp. 421-448.

Radzinski, K.-H., 1999. Zur lithostratigraphischen Gliederung der Bernburg-Formation (Unterer Buntsandstein) im mittleren und nördlichen Teil von Sachsen-Anhalt. Mitt. Geol. Sachsen-Anhalt 5, 73-93.

Radzinski, K.-H., 2008. 4.9.2 Buntsandstein. In: Bachmann, G.H., Ehling, B.-C., Eichner, R., Schwab, M. (Eds), Geologie von Sachsen-Anhalt. E. Schweizerbart'sche Verlagsbuchhandlung (Nägle u. Obermiller), Stuttgart, pp. 180-200.

Reichow, M.K., Saunders, A.D., White, R.V., Pringle, M.S., Al'Mukhamedov, A.I., Medvedev, A.I., Kirda, N.P., 2002. 40Ar/39Ar Dates from the West Siberian Basin: Siberian Flood Basalt Province Doubled. Science 296, 1846-1849.

Reichow, M.K., Pringle, M.S., Al'Mukhamedov, A.I., Allen, M.B., Andreichev, V.L., Buslov, M.M., Davies, C.E., Fedoseev, G.S., Fitton, J.G., Inger, S., Medvedev, A.Ya., Mitchell, C., Puchkov, V.N., Safonova, I.Yu., Scott, R.A., Saunders, A.D., 2009. The timing and extent of the eruption of the Siberian Traps large igneous province: Implications for the end-Permian environmental crisis. Earth and Planetary Science Letters 277, 9-20.

Riccardi, A., Kump, L.R., Arthur, M.A., D’Hondt, S., 2007. Carbon isotopic evidence for chemocline upward excursions during the end-Permian event. Palaeogeogr. Palaeoclimat. Palaeoecol. 248, 7381.

Richoz, S., Krystyn, L., Baud, A., Brandner, R., Horacek, M., Mohtat-Aghai, P., 2010. Permian-Triassic boundary interval in the Middle East (Iran and N. Oman): Progressive environmental change from detailed carbonate carbon isotope marine curve and sedimentary evolution. Journal of Asian Earth Sciences 39, 236-253.

Richter-Bernburg, G., 1955. Stratigraphische Gliederung des deutschen Zechsteins. Zeitschrift der Deutschen Geologischen Gesellschaft 105, 843-854.

Röhling, H.-G., 2013. Der Buntsandstein im Norddeutschen Becken - regionale Besonderheiten. In: Deutsche Stratigraphische Kommission, Lepper, H.-G., Röhling, H.-G. (Eds.), Stratigraphie von 
Deutschland XI. Buntsandstein. Schriftenreihe der Deutschen Gesellschaft für Geowissenschaften 69, pp. 269-384.

Röhling, H.-G., Lepper, J., 2013. Paläogeographie des Mitteleuropäischen Beckens während der tieferen Trias (Buntsandstein). In: Deutsche Stratigraphische Kommission, Lepper, H.-G., Röhling, H.G. (Eds.), Stratigraphie von Deutschland XI. Buntsandstein. Schriftenreihe der Deutschen Gesellschaft für Geowissenschaften 69, pp. 43-67.

Roscher, M., Stordal, F., Svensen, H., 2011. The effect of global warming and global cooling on the distribution of the latest Permian climate zones. Palaeogeogr. Palaeoclimat. Palaeoecol. 309, 186200.

Roth, W., 1975. Stratigraphische, lithofazielle und paläotektonische Untersuchungen im Buntsandstein (Nordhausen- bis Solling-Folge) des Subherzynen Beckens. PhD thesis, Bergakademie Freiberg, Freiberg.

Sadovnikov, G.N., 2015. Paleoecological Characterization of the Middle Siberian Trappean Plateau during the Middle Period of Its Formation (Terminal Permian). Paleontological Journal 49 (4), 438447.

Sadovnikov, G.N., 2016. Evolution of the Biome of the Middle Siberian Trappean Plateau. Paleontologiceskij zurnal, 2016 (5), 87-99.

Sanson-Barrera, A., Hochuli, P.A., Bucher, H., Schneebeli-Hermann, E., Weissert, H., Adatte, T., Bernasconi, S.M., Late Permian-earliest Triassic high-resolution organic carbon isotope and palynofacies records from Kap Stosch (East Greenland). Global and Planetary Change 133, 149-166.

Schneider, J.W., Scholze, F., in press. Late Pennsylvanian to Early Triassic conchostracan biostratigraphy - a preliminary approach. In: Lucas, S.G., Shen, S. (Eds.), The Permian Timescale. Geol. Soc. London Spec. Publ. 450. [accepted]

Schneider, J.W., Rössler, R., Werneburg, R., Scholze, F., Voigt, S., 2014. Part II. The CarboniferousPermian basins in Saxony, Thuringia, and Saxony-Anhalt of East Germany. In: Schneider, J.W., Oplustil, S., Scholze, F. (Eds.), CPC-2014 Field Meeting on Carboniferous and Permian NonmarineMarine Correlation. July $21^{\text {st }}-27^{\text {th }}$, Freiberg, Germany. Excursion Guide. Wissenschaftliche Mitteilungen 46, pp. 55-121.

Scholze, F., 2011. Sedimentologie, Paläontologie und Geochemie im Zechstein und Buntsandstein von Sachsen-Anhalt und Thüringen. Diploma thesis, Institut für Geologie, Technische Universität Bergakademie Freiberg, Freiberg.

Scholze, F., 2014. Comparison of Late Permian to Early Triassic conchostracan faunas in Germany and Russia. In: Nurgaliev, D.K., Silantiev, V.V., Urazaeva, M.N. (Eds.), Kazan Golovkinsky Stratigraphic Meeting, 2014, Carboniferous and Permian Earth systems, stratigraphic events, biotic evolution, sedimentary basins and resources, October, 20-23, Kazan, Russia. Kazan Federal University, Institute of geology and petroleum technologies, Kazan, pp. 78-79.

Scholze, F., 2016. Sedimentary structures and facies interpretation of the continental PermianTriassic boundary section in the Caaschwitz Quarries (eastern Thuringia, central Germany). In: 
Niebuhr, B., Wilmsen, M., Kunzmann, L., Stefen, C. (Eds.), $87^{\text {th }}$ Annual Conference of the Paläontologische Gesellschaft e.V. Dresden September 11-15 2016, Saxoprint GmbH Dresden, Dresden, p. 140.

Scholze, F., Schneider, J.W., 2013. Multistratigraphic reinvestigation of the Permian-Triassic boundary (PTB) in continental deposits of Central Germany. In: Reitner, J., Qun, Y., Yangdong, W., Reich, M. (Eds), Palaeobiology and Geobiology of Fossil Lagerstätten through Earth History, A Joint Conference of the "Paläontologische Gesellschaft" and the "Palaeontological Society of China", Göttingen, Germany, September 23-27, 2013, Universitätsverlag Göttingen, Gottingen, pp. 147-148.

Scholze, F., Schneider, J.W., 2015. Improved methodology of 'conchostracan' (Crustacea: Branchiopoda) classification for biostratigraphy. Newsl. Stratigr. 48, 287-298.

Scholze, F., Schneider, J.W., Elicki, O., 2011. Mikrofossilien aus Oolithen des Unteren Buntsandstein (Bernburg-Formation, Untere Trias) von Sachsen-Anhalt. In: Verein zur Förderung der Paläontologie (Edi.), 82. Jahrestagung der Paläontologischen Gesellschaft in Wien. Beiträge zur Paläontologie 32, p. 75 .

Scholze, F., Schneider, J.W., Wang, X., Joachimski, M., 2014. Nonmarine-marine correlation of the Permian-Triassic boundary: First results from a new multistratigraphic research project. In: Elicki, O., Schneider, J.W., Spindler, F. (Eds.), CPC-2014 Field Meeting on Carboniferous and Permian Nonmarine-Marine Correlation. July $21^{\text {st }}-27^{\text {th }}$, Freiberg, Germany. Wissenschaftliche Mitteilungen 45, pp. 57-58.

Scholze, F., Golubev, V.K., Niedźwiedzki, G., Sennikov, A.G., Schneider, J.W., Silantiev, V.V., 2015. Early Triassic Conchostracans (Crustacea: Branchiopoda) from the terrestrial Permian-Triassic boundary sections in the Moscow syncline. Palaeogeogr. Palaeoclimat. Palaeoecol. 429, 22-40.

Scholze, F., Schneider, J.W., Werneburg, R., 2016. Conchostracans in continental deposits of the Zechstein-Buntsandstein transition in central Germany: Taxonomy and biostratigraphic implications for the position of the Permian-Triassic boundary within the Zechstein Group. Palaeogeogr. Palaeoclimat. Palaeoecol. 449, 174-193.

Scholze, F., Abu Hamad, A., Schneider, J.W., Golubev, V.K., Sennikov, A.G., Voigt, S., Uhl, D., 2017. An enigmatic 'conchostracan' fauna in the eastern Dead Sea region of Jordan: First records of Rossolimnadiopsis Novozhilov from the Early Triassic Ma'in Formation. Palaeogeogr. Palaeoclimat. Palaeoecol. 466, 314-325.

Schulze, G., 1969. Der Untere Buntsandstein der Scholle von Calvörde und benachbarter Gebiete. Geologie 18 (1), 5-20.

Sciscio, L., Bordy, E.M., 2016. Palaeoclimatic conditions in the Late Triassic-Early Jurassic of southern Africa: A geochemical assessment of the Elliot Formation. Journal of African Earth Sciences 119, 102 119.

Sheldon, N.D., Tabor, N.J., 2009. Quantitative paleoenvironmental and paleoclimatic reconstruction using paleosols. Earth-Science Reviews 95, 1-52. 
Shen, S.-z., Crowley, J. L., Wang, Y., Bowring, S.A., Erwin, D.H., Sadler, P.M., Cao, C.-q., Rothman, D.H., Henderson, C.M., Ramezani, J., Zhang, H., Shen, Y., Wang, X.-d., Wang, W., Mu, L., Li, W.-z., Tang, Y.g., Liu, X.-I., Liu, L.-j., Zeng, Y., Jiang, Y.-f., Jin, Y.-g., 2011. Calibrating the End-Permian Mass Extinction. Science 334, 1367-1372.

Siegert, S., Kraus, S.H., Mette, W., Struck, U., Korte, C., 2011. Organic carbon isotope values from the Late Permian Seis/Siusi succession (Dolomites, Italy): Implications for palaeoenvironmental changes. Fossil Record 14 (2), 207-217.

Song, H., Wignall, P.B., Chu, D., Tong, J., Sun, Y., Song, H., He, W., Tian, L., 2014. Anoxia/high temperature double whammy during the Permian-Triassic marine crisis and its aftermath. Scientific Reports 4, 1-7.

Stampfli, G.M., Borel, G.D., 2002. A plate tectonic model for the Paleozoic and Mesozoic constrained by dynamic plate boundaries and restored synthetic oceanic isochrons. Earth and Planetary Science Letters 196, 17-33.

Svensen, H., Planke, S., Plozov, A.G., Schmidbauer, N., Corfu, F., Podladchikov, Y.Y., Jamtveit, B., 2009. Siberian gas venting and the end-Permian environmental crisis. Earth and Planetary Science Letters $277,490-500$.

Szurlies, M., 1999. Zyklenstratigraphie und Gamma-Ray-Log-Korrelation im Unteren Buntsandstein (Untere Trias) des nördlichen Harzvorlandes. Hallesches Jahrb. Geowiss. B 21, 35-53.

Szurlies, M., 2001. Zyklische Stratigraphie und Magnetostratigraphie des Unteren Buntsandsteins in Mitteldeutschland. PhD thesis, Martin-Luther-Universität Halle-Wittenberg, Halle.

Szurlies, M., Geluk, M.C., Krijgsman, W., Kürschner, W.M., 2012. The continental Permian-Triassic boundary in the Netherlands: Implications for the geomagnetic polarity time scale. Earth and Planetary Science Letters 317-318, 165-176.

Szurlies, M., 2013. Late Permian (Zechstein) magnetostratigraphy in Western and Central Europe. Geol. Soc., London, Spec. Pub. 376, 73-85.

Szurlies, M., Bachmann, G.H., Menning, M., Nowaczyk, N.R., Käding, K.-C., 2003.

Magnetostratigraphy and high-resolution lithostratigraphy of the Permian-Triassic boundary interval in Central Germany. Earth and Planetary Science Letters 212, 263-278.

Takahashi, S., Kaiho, K., Oba, M., Kakegawa, T., 2010. A smooth negative shift of organic carbon isotope ratios at an end-Permian mass extinction horizon in central pelagic Panthalassa. Palaeogeogr. Palaeoclimat. Palaeoecol. 292, 532-539.

Talbot, M.R., 1990. A review of the palaeohydrological interpretation of carbon and oxygen isotopic ratios in primary lacustrine carbonates. Chemical Geology (Isotope Geoscience Section) 80, 261-279.

Taylor, G.K., Tucker, C., Twichett, R.J., Kearsey, T., Benton, M.J., Newell, A.J., Surkov, M.V., Tverdokhlebov, V.P., 2009. Magnetostratigraphy of Permian/Triassic boundary sequences in the CisUrals, Russia: No evidence for a major temporal hiatus. Earth Planet. Sc. Lett. 281, 36-47.

Tauxe, L., 2010. Essentials of Paleomagnetism, University of California Press, Berkeley. 
Thomas, B.S., Willink, R.J., Grice, K., Twitchett, R.J., Purcell, R.R., Archbold, N.W., George, A.D., Tye, S., Alexander, R., Foster, C.B., Barber, C.J., 2004. Unique marine Permian-Triassic boundary section from Western Australia. Australian Journal of Earth Sciences 51, 423-430.

Thomas, S.G., Tabor, N.J., Yang, W., Myers, T.S., Yang, Y., Wang, D., 2011. Palaeosol stratigraphy across the Permian-Triassic boundary, Bogda Mountains, NW China: Implications for palaeoenvironmental transition through earth's largest mass extinction. Palaeogeogr. Palaeoclimat. Palaeoecol. 308, 41-64.

Tyson, R.V., 1995. Sedimentary Organic Matter: Organic Facies and Palynofacies. Chapman \& Hall, London, $615 \mathrm{pp}$.

Usdowski, H.-E., 1963. Der Rogenstein des norddeutschen Unteren Buntsandsteins, ein Kalkoolith des marinen Faziesbereichs. Fortschr. Geol. Rheinld. u. Westf. 10, 337-342.

Voigt, T., Gaupp, R., 2000. Die fazielle Entwicklung an der Grenze zwischen Unterem und Mittlerem Buntsandstein im Zentrum der Thüringer Senke. Beitr. Geol. Thüringen N.F. 7, 55-71.

Voigt, S., Hauschke, N., Schneider, J.W., 2008. Nachweis fossiler Notostraken in Deutschland - ein Überblick. Abhandlungen und Berichte für Naturkunde 31, 7-24.

Wagenbreth, O., 1968. Stratigraphische, petrographische und paläontologische Beobachtungen im Buntsandstein von Staßfurt-Egeln-Oschersleben. Geologie 17 (8), 885-901.

Ward, P.D., Montgomery, D.R., Smith, R., 2000. Altered River Morphology in South Africa Related to the Permian-Triassic Extinction. Science 289, 1740-1743.

Weidlich, O., 2007. PTB mass extinction and earliest Triassic recovery overlooked? New evidence for a marine origin of Lower Triassic mixed carbonate-siliciclastic sediments (Rogenstein Member), Germany. Palaeogeogr. Palaeoclimat. Palaeoecol. 252, 259-269.

Xie, S., Pancost, R.D., Yin, H., Wang, H., Evershed, R.P., 2005. Two episodes of microbial change coupled with Permo/Triassic faunal mass extinction. Nature 434, 494-497.

Xie, S., Pancost, R.D., Huang, X., Jiao, D., Lu, L., Huang, J., Yang, F., Evershed, R.P., 2007. Molecular and isotopic evidence for episodic environmental change across the Permo/Triassic boundary at Meishan in South China. Global and Planetary Change 55, 56-65.

Xie, S., Wang, Y., 2011. Geomicrobiological perspective on the pattern and causes of the 5-millionyear Permo/Triassic biotic crisis. Front. Earth Sci. 5 (1), 23-36.

Yu, J., Peng, Y., Zhang, S., Yang, F., Zhao, Q., Huang, Q., Terrestrial events across the Permian-Triassic boundary along the Yunnan-Guizhou border, SW China. Global and Planetary Change 55, 193-208.

Zhang, H., Cao, C.-q., L, X.-I., Mu, L., Zheng, Q.-f., Liu, F., Xiang, L., Liu, L.-j., Shen, S.-z., 2016. The terrestrial end-Permian mass extinction in South China. Palaeogeogr. Palaeoclimat. Palaeoecol. 448, 108-124.

Ziegler, A.M., 1990a. Geological Atlas of Western and Central Europe. Shell Internationale Petroleum Maatschappij, The Hague. 
Zijderveld, J.D.A., 1967. A.C. demagnetization of rocks: analysis of results. In: Collinson, D.W., Creer, K.M., Runcorn, S.K. (Eds.), Methods in Paleomagnetism, Elsevier, Amsterdam, pp. 254-286.

\section{Online Supplements (Appendix):}

Supplement 1. Results of major- and trace-element analyses from the Caaschwitz 6/2012 drill core section (Thuringia, central Germany) ranging from the Leine Formation ( $z 3$, Zechstein Group) to the Calvörde Formation (Lower Buntsandstein Subgroup).

Supplement 2. Results of $\delta^{13} \mathrm{C}_{\mathrm{carb}, \mathrm{VPDB}}$ and $\delta^{18} \mathrm{O}_{\mathrm{carb}, \mathrm{VPDB}}$ analyses from the studied Late Permian to Early Triassic sections. The data were obtained from bulk carbonate isotope measurements of samples of the Zechstein-Buntsandstein transition in Germany.

Supplement 3. Results of $\delta^{13} \mathrm{C}_{\text {org }}$ analyses from the studied Late Permian to Early Triassic sections. The data was obtained from siliciclastic and carbonate bulk sediment isotope measurements of samples of the Zechstein-Buntsandstein transition in Germany.

Supplement 4. Results of major- and trace-element analyses from the abandoned clay pit section at Nelben (Saxony-Anhalt, central Germany) ranging from the Upper Fulda Formation (upper z7, Zechstein Group) to the Calvörde Formation (Lower Buntsandstein Subgroup).

Supplement 5. Curves showing the absolute contents of major- and trace-element analyses from the abandoned clay pit section at Nelben ranging from the Upper Fulda Formation (upper z7, Zechstein Group) to the Calvörde Formation (Lower Buntsandstein Subgroup). 